IZA DP No. 7355

\title{
Economic Conditions and Child Abuse
}

Jason M. Lindo

Jessamyn Schaller

Benjamin Hansen

April 2013 


\title{
Economic Conditions and Child Abuse
}

\author{
Jason M. Lindo \\ University of Oregon, \\ NBER, IZA and University of Wollongong \\ Jessamyn Schaller \\ University of Arizona \\ Benjamin Hansen \\ University of Oregon
}
Discussion Paper No. 7355
April 2013

IZA

P.O. Box 7240

53072 Bonn

Germany

Phone: +49-228-3894-0

Fax: +49-228-3894-180

E-mail: iza@iza.org

Any opinions expressed here are those of the author(s) and not those of IZA. Research published in this series may include views on policy, but the institute itself takes no institutional policy positions. The IZA research network is committed to the IZA Guiding Principles of Research Integrity.

The Institute for the Study of Labor (IZA) in Bonn is a local and virtual international research center and a place of communication between science, politics and business. IZA is an independent nonprofit organization supported by Deutsche Post Foundation. The center is associated with the University of Bonn and offers a stimulating research environment through its international network, workshops and conferences, data service, project support, research visits and doctoral program. IZA engages in (i) original and internationally competitive research in all fields of labor economics, (ii) development of policy concepts, and (iii) dissemination of research results and concepts to the interested public.

IZA Discussion Papers often represent preliminary work and are circulated to encourage discussion. Citation of such a paper should account for its provisional character. A revised version may be available directly from the author. 


\section{ABSTRACT}

\section{Economic Conditions and Child Abuse*}

Although a huge literature spanning several disciplines documents an association between poverty and child abuse, researchers have not found persuasive evidence that economic downturns increase abuse, despite their impacts on family income. In this paper, we address this seeming contradiction. Using county-level child abuse data spanning 1996 to 2009 from the California Department of Justice, we estimate the extent to which a county's reported abuse rate diverges from its trend when its economic conditions diverge from trend, controlling for statewide annual shocks. The results of this analysis indicate that overall measures of economic conditions are not strongly related to rates of abuse. However, focusing on overall measures of economic conditions masks strong opposing effects of economic conditions facing males and females: male layoffs increase rates of abuse whereas female layoffs reduce rates of abuse. These results are consistent with a theoretical framework that builds on family-time-use models and emphasizes differential risks of abuse associated with a child's time spent with different caregivers.

JEL Classification: $\quad 110, \mathrm{~J} 13, \mathrm{~J} 16, \mathrm{~J} 63, \mathrm{~K} 42$

Keywords: child abuse, recessions, job loss, time use, gender, childcare

Corresponding author:

Jason M. Lindo

University of Oregon

Department of Economics

1285 University of Oregon

Eugene, OR 97403

USA

E-mail: jlindo@uoregon.edu

\footnotetext{
* The authors thank Steven Haider, Hilary Hoynes, Magnus Lofstrom, Ron Oaxaca, Nick Sly, Gary Solon, Peter Siminski, Glen Waddell, Sally Wallace, Wes Wilson, and Madeline Zavodny for valuable feedback, in addition to seminar participants at Arizona State University, Louisiana State University, Michigan State University, Texas A\&M University, University of Oregon, University of Illinois at Urbana- Champaign, and University of Wollongong and conference participants at the IZA's 5th Annual Meeting on the Economics of Risky Behaviors. Lindo gratefully acknowledges the Center for the Study of Women in Society at the University of Oregon for financial support. Schaller gratefully acknowledges financial support from the UC Davis and Humanities Graduate Research Fellowship.
} 


\section{Introduction}

In 2010, Child Protective Services identified 121,380 victims of physical abuse, 55,405 victims of psychological abuse, and 63,527 victims of sexual abuse in the United States. ${ }^{1}$ Child abuse has grave consequences both for victims and for society. In addition to the immediate suffering that they experience, abused children suffer from poor physical and emotional health and are at increased risk for depression, behavioral problems, and high-risk health behaviors (Fletcher 2009, Thornberry, Henry, Ireland, and Smith 2010). Maltreatment also has important long-term implications, as maltreated children are more likely to be unemployed, in poverty, and using Medicaid in adulthood (Zielinski 2009, Currie and Widom 2010) and are more likely to commit crimes (Currie and Tekin 2012). Meanwhile, child abuse imposes a number of direct and indirect costs on society - costs of hospitalization and ongoing physical and mental health care for victims, expenses for law enforcement and child welfare agencies, increased pressure on the criminal justice system, and lost productivity.

While the existing literature has firmly established that economic circumstances are a key predictor of child abuse, the extent to which this relationship is causal remains unclear. The main challenge to estimating the causal link is that unobserved characteristics that lead to relatively-poor economic outcomes (e.g., mental health problems, high discount rates) may also contribute to a parent's likelihood of abusing children. As such, in order to convincingly identify the causal effect, it is necessary to consider plausibly-exogenous sources of variation in economic circumstances. One such source is changes in macroeconomic conditions. If economic circumstances are causally linked with the probability of abuse, it seems natural to think that economic downturns would cause rates of abuse to increase. Perhaps surprisingly, the existing evidence on the relationship between macroeconomic conditions and child abuse is actually mixed. Despite the onset of our most recent recession and the declines in family income that followed, victimization rates have actually fallen slightly from 2007 to 2010 (from 9.6 per 1,000 children to 9.2 per 1,000 children), continuing along a downward trajectory that has spanned nearly two

\footnotetext{
${ }^{1}$ These statistics are reported in U.S. Department of Health and Human Services (2011).
} 
decades (U.S. Department of Health and Human Services 2011). Three prior economic studies that use panel-data techniques and exploit changes in local economic conditions to identify this relationship also support the notion that the causal link is weak (Paxson and Waldfogel 2002, Bitler and Zavodny 2004, and Seiglie 2004). ${ }^{2}$

This paper reexamines the causal link between economic conditions and child abuse but departs from this earlier literature by focusing on gender-specific measures of economic conditions. This emphasis is motivated by the notion that changes in economic conditions facing males and females may have different effects on family income, stress, substance abuse, divorce, and other aspects of the household that influence child abuse. Moreover, as we discuss in greater detail below, changing economic conditions facing males and females are likely to have asymmetrical effects on household bargaining and childcare provision, implying that changing economic conditions facing males and females may have asymmetrical effects on child abuse.

Our empirical analysis uses county-level abuse statistics from the California Department of Justice. Following a large prior literature examining the effects of economic conditions on health outcomes sparked by Ruhm (2000), our estimates are based on regression models that control for county fixed effects, county-specific trends, and year fixed effects. Assuming that unobservable variables related to abuse do not deviate from a county's trend when its economic conditions deviate from trend, this approach will uncover the causal effect of local economic conditions. After estimating the effects of standard proxies for aggregate economic conditions - unemployment rates and employment-to-population ratios - we test for heterogeneous effects of labor market conditions facing males and females by using separate counts of males and females involved in mass layoffs to construct gender-specific measures of local economic conditions.

Like other researchers, we find that overall changes in economic conditions are not significantly related to reports of abuse. However, overall measures of economic conditions mask strong opposing effects of economic conditions facing males and females. In partic-

\footnotetext{
${ }^{2}$ There is some evidence based on hospital records, which we discuss in greater detail below, that suggests that economic downturns are associated with increases in hospital admissions for abuse-related injuries (Wood, Medina, Feudtner, Luan, Localio, Fieldston, and Rubin 2012).
} 
ular, downturns that disproportionately affect males increase abuse while downturns that disproportionately affect females reduce abuse. These results are robust to the inclusion of demographic controls and controls for employment in sectors that are responsible for most reports of child abuse.

While our identification strategy does not allow us to pin down the mechanisms underlying these effects, the pattern of estimates is quite informative. In particular, because both male and female job losses are likely to induce stress, substance abuse, and changes in family structure, any model of the household that focuses on these mechanisms will not be able to explain the asymmetry uncovered by our empirical analysis. ${ }^{3}$ This leaves household bargaining and childcare provision as the most likely keys to understanding why male layoffs increase child abuse while female layoffs reduce child abuse. However, it seems unlikely that reducing women's bargaining power would promote children's welfare, especially in light of earlier work showing that women's bargaining power is negatively related to domestic violence (Aizer 2010). In contrast, a family-time-use model of the household that emphasizes differential risks of abuse associated with a child's time spent with different caregivers can explain the pattern of estimates in a straightforward and intuitive manner: men's job losses can increase child abuse by shifting childcare provision towards those with relatively high propensities to abuse children (fathers) while women's job losses can reduce child abuse by shifting childcare provision towards those with relatively low propensities to abuse children (mothers). ${ }^{4}$

In order to gain insight into plausibility of this explanation, we supplement our analysis of abuse reports with an investigation of the relationship between parental employment and time spent with children using data from the American Time Use Survey. This analysis exploits the fact that American Time Use Survey participants are drawn from households that recently participated in a Current Population Survey. In particu-

\footnotetext{
${ }^{3}$ Specifically, Eliason and Storrie (2009a) and Eliason and Storrie (2009b) show that both male and female job losses leads to increased risk of hospitalization and death from self-harm or alcohol-related causes while Charles and Stephens Jr (2004) and Eliason (2012) show that both male and female job losses increase the risk of divorce.

${ }^{4}$ We discuss differential risks of abuse associated with different childcare providers in detail in Section 2. That said, the fact that fathers have higher abuse propensities than mothers should come as no surprise; it is well established that males are disproportionately represented among those with behavior problems, though why this gender gap exists is less clear (Bertrand 2011).
} 
lar, we consider current time with children as a function of current employment status and spouse's current employment status within groups of families who recently had very similar economic circumstances, as defined by the triple-interaction of the father's employment status, the mother's employment status, and the family's income category at the time of the Current Population Survey. Consistent with the predictions of familytime-use models (Lundberg 1985, Killingsworth and Heckman 1987, Stephens 2002), we find that non-employment is positively related to childcare and spousal non-employment is negatively related to childcare for both fathers and mothers, providing support for the notion that the effects of job loss on child abuse may be driven by impacts on the distribution of childcare.

This paper makes several contributions to the literature. In addition to being one of a handful of studies to estimate the causal effects of economic conditions on child abuse, we have demonstrated why establishing the causal link has been so elusive. Moreover, the pattern of estimates suggests that childcare provision may play a pivotal role in determining how economic shocks affect child abuse.

We also contribute to a small but growing literature in economics that uses genderspecific economic conditions to test the implications of economic models of individual and family decision-making (Blau, Kahn, and Waldfogel 2000, Qian 2008, Aizer 2010, Schaller 2012). Given the dramatic rise in female labor force participation and the prevalence of dual-earner families, models that allow for separate effects of shocks to male and female labor market opportunities are increasingly relevant. The results from this paper suggest that a gender-specific approach may be particularly important for understanding of the effects of economic shocks on child outcomes.

\section{Background}

\subsection{Victims and Perpetrators of Abuse}

According to a 2010 report to Congress based on the Fourth National Incidence Study of Child Abuse and Neglect (NIS-4), 553,000 children experienced demonstrable harm 
resulting from abuse during a single study year (2005-06). ${ }^{5}$ Fifty-eight percent of these abused children were victims of physical abuse, while 24 percent were sexually abused and 27 percent were emotionally abused.

Eighty-four percent of abused children were harmed by either their biological parent or a non-biological parent or partner. Other relatives account for a majority of the remainder while day-care providers are responsible for less than one percent. Fathers and father figures are over-represented as perpetrators of child abuse, especially when abuse rates are adjusted for time spent with children (Guterman and Lee 2005, Dubowitz et al. 2006, Francis and Wolfe 2008, Lee, Bellamy, and Guterman 2009). For example, males played a role in 62 percent of abuse cases reported in NIS-4 whereas females played a role in 41 percent of such cases, despite the fact that mothers spend 50 to 160 percent more time with children than fathers in two-parent households, depending on how time with children is defined. ${ }^{6}$ Naturally, the fact that there are dramatic differences in risks associated with a child's time spent with different childcare providers implies that childcare provision may be an important mechanism through which economic shocks affect rates of abuse.

\subsection{Reporting of Abuse}

Each state has legislation mandating that certain professionals and institutions report suspected abuse to a CPS agency. Mandatory reporters such as teachers, law enforcement and legal personnel, social services staff, childcare providers, clergy members, and health care personnel contribute the majority of allegations of abuse (about three fifths), with nonprofessional reporters such as relatives, parents, friends, and neighbors making up the remaining share. Upon receiving initial referrals, CPS agencies respond to allegations of abuse in a two-stage process. First, the agency determines whether the referral meets state standards for response by a CPS agency. Then, screened-in refer-

\footnotetext{
${ }^{5}$ The NIS-4 is a congressionally mandated study by the United States Department of Health and Human Services that measures the total number of children abused and neglected in the United States. The study collects data on children investigated by Child Protective Services (CPS) agencies and also gathers data from additional sources to estimate the scope of maltreatment beyond official statistics. Notably, the CPS only identified 326,000 abused children in 2006.

${ }^{6}$ Based on the authors' calculations using data from the American Time Use Survey. See Section 4.1 for a description of the time use analysis and Table 6 for summary statistics.
} 
rals become "reports" and receive either an investigation or an alternative response from child-welfare workers. After CPS investigation, reports are categorized as substantiated or unsubstantiated according to state law or policy.

While there is no doubt that false reports are sometimes made, the consensus view is that statistics tend to understate the true prevalence of child abuse because underreporting is such a serious issue (Waldfogel 1998, Sedlak, Mettenburg, Basena, Peta, McPherson, Greene, et al. 2010). In fact, the NIS-4, which identifies maltreated children outside of the CPS system, found that CPS investigated the maltreatment of only 32 percent of children identified in the study as having experienced observable harm from maltreatment. Applying CPS screening criteria to the maltreatment cases that were not investigated by CPS, the researchers concluded that underreporting was the primary reason for this low rate of investigation: three quarters of the cases would have been investigated if they had been reported to CPS. Given that only a fraction of abuse is reported, data quality is an important concern for all studies of child abuse. We return to this issue in subsequent sections.

\subsection{Related Research on Economic Conditions and Child Abuse}

Official statistics leave little doubt that rates of child abuse differ significantly across family socioeconomic status. According to the NIS-4, children in families with lowsocioeconomic status, as measured by a composite of household income, educational attainment, and poverty-program receipt, are at significantly greater risk of abuse than other children (7.7 versus 2.5 children per 1,000). Additionally, the incidence rate is higher in families in which at least one parent is unemployed (4.8 children per 1,000) than in families in which both parents are employed (3.9 children per 1,000). Moreover, families in which at least one parent is not in the labor force have an incidence rate that is more than two times that of families with employed parents (9.6 children per 1,000). Family structure is also highly related to the incidence of child abuse - children with married biological parents are at the lowest risk of abuse, with an incidence rate of only 2.9 children per 1,000, while children with a step-parent, children with unmarried 
parents, and children of a single parent with a partner have dramatically higher rates of abuse, at 17.4, 12.1, and 33.6 children per 1,000, respectively (Sedlak, Mettenburg, Basena, Peta, McPherson, Greene, et al. 2010).

A large literature spanning an array of disciplines is dedicated to documenting similar patterns of child maltreatment. Research using a variety of data sources over more than four decades provides strong evidence that children in poor families and disadvantaged neighborhoods experience disproportionately high rates of maltreatment. ${ }^{7}$ Additionally, a number of studies link parental unemployment to abuse rates (Gil 1970, Light 1973, Gillham, Tanner, Cheyne, Freeman, Rooney, and Lambie 1998).

Despite the large number of studies on the topic, little progress has been made in identifying causal effects of socioeconomic factors on rates of abuse. As the majority of existing studies use cross-sectional data, most are subject to the concern that unobservable parental characteristics related to abuse may also be correlated with parental labor market outcomes and family income. A few researchers have made progress on this front through the use of panel data techniques and plausibly exogenous aggregate proxies for family socioeconomic status. In an early longitudinal study, Steinberg, Catalano, and Dooley (1981) find that increases in child abuse in two metropolitan counties are preceded by periods of high job loss. More recent studies use state-level panel data to estimate the effects of a variety of economic indicators on abuse rates, finding mixed results. In particular, Paxson and Waldfogel $(1999,2002)$ find that increases in child poverty raise physical abuse but that increases in unemployment rates decrease physical abuse, while Seiglie (2004) and Bitler and Zavodny $(2002,2004)$ find no statistically significant effects of unemployment rates on the incidence of physical or total abuse. More recently, Wood, Medina, Feudtner, Luan, Localio, Fieldston, and Rubin (2012) focus on hospital admissions for abuse-related injuries. Using panel data from 38 hospitals from 2000-2009, they estimate a hospital fixed effects model, using local unemployment, mortgage delinquency, and foreclosure rates to measure economic conditions. Their results suggest that local economic downturns significantly increase the incidence of severe-physical abuse.

\footnotetext{
${ }^{7}$ For example, see Gil (1970), Garbarino (1976), Garbarino and Kostelny (1992), Gelles (1992), and Coulton, Korbin, Su, et al. (1999).
} 
However, the statistical significance of their estimates is questionable since they do not account for the likely autocorrelation in the error terms within hospitals over time, which would serve to widen their confidence intervals.

\section{Analyzing The Effect of Economic Conditions on Child Abuse}

\subsection{Data}

We bring together data from several sources in order to estimate the effects of economic conditions on child abuse. Our abuse data are based on counts submitted to the California Department of Justice by county welfare and probation departments. ${ }^{8}$ These data consist of allegations of abuse that were screened-in in the initial stage of evaluation and investigated by child welfare agencies between 1996 and 2009. We have separate measures of physical abuse, psychological abuse, and sexual abuse. Physical abuse cases typically involve bruising, pressure sores, bleeding, malnutrition, dehydration, burns, bone fractures, soft-tissue swelling, or internal injuries. Psychological abuse cases involve blaming, belittling, or rejecting a child, treating siblings unequally, and persistent lack of concern for the child's welfare. Sexual abuse cases involve children in sexual activities for which they are unable to give informed consent. We combine these abuse data with population counts from the National Health Interview Survey (NHIS) Cancer Surveillance, Epidemiology, and End Results Program (SEER) in order to create rates of abuse per 100,000 children, which we use as the outcome variable in our analyses. We also use the NHIS population counts to construct demographic control variables, i.e., the fraction of the population that is black, Hispanic, and neither white nor Hispanic.

Our analysis of county-level data within a single state is motivated by two serious concerns about state-level data. The first is a lack of comparability of data on reported and substantiated abuse across states. States differ in how they define abuse, who is required to report abuse, and in how they record and respond to reports of abuse. A

\footnotetext{
${ }^{8}$ These data were acquired from RAND California.
} 
second concern with state-level data is that we are unable to observe changes in definitions of abuse, reporting expectations, and standards for screening allegations of abuse that may have substantial implications for the number of reports that are observed in a given year. Because these confounding factors vary primarily at the state level rather than the county level, we are able to adjust for them in our analysis by controlling for year fixed effects. ${ }^{9}$

The major limitation of our abuse data is that they lack information on the characteristics of perpetrators and victims. As such, our estimates will be able to speak to the extent to which changing economic conditions affect reports of abuse but will not be able to shed light on whether any observed effects are driven by changes in behavior among specific groups of adults (e.g., males or females, parents or strangers, etc.) or by changes in the abuse of specific groups of children (e.g., males or females, young children or older children, etc.). We view research on these potential sources of heterogeneity as an important area for future work. Nonetheless, the narrow spatial dimension of the data make them quite useful for identifying the effects of changing economic conditions. In particular, as we elaborate upon in the next section, this aspect of the data allows us to leverage variation across counties in the timing and severity of the two recessions spanned by the data to identify the causal effects of economic conditions.

As we alluded to in Section 2, data quality is an issue for all studies of child abuse. Given that our outcome variables are based on reports of abuse - and reports of abuse can diverge from the true amount of abuse for a variety of reasons - they are best thought of as a proxy for the outcome of interest. For our purposes, there are two primary concerns with using such a proxy. First, given the extent of underreporting, our constructed measure of child abuse will likely understate the true extent of child abuse. That said, the bias that this issue might otherwise introduce can be eliminated by considering the effects in percentage terms rather than in levels. Second, if economic conditions have an effect on reports of abuse that is independent of effects on actual cases of abuse, estimates of the effect of economic conditions will be biased. Out of concern for this

\footnotetext{
${ }^{9}$ For further discussion the limitations of state-level data, see Paxson and Waldfogel (1999) and Wood, Medina, Feudtner, Luan, Localio, Fieldston, and Rubin (2012).
} 
possibility, we incorporate controls for employment per capita in the highest reporting sectors into our analysis. In particular, we obtain information on employment per capita in primary and secondary schools, social services, and hospitals from the US Census Bureau's County Business Patterns and employment per capita in law enforcement from the Uniform Crime Report's Law Enforcement Officers Killed and Assaulted (LEOKA) database. In 2010, law enforcement personnel, school employees, social services workers, and medical professionals were responsible for 16.7, 16.4, 11.5, and 8.2 percent of reports to Child Protective Services, respectively (US Department of Health and Human Services 2011).

We consider several different measures of local economic conditions in our analysis. As a starting point, we use unemployment rates produced by the Bureau of Labor Statistics (BLS), the most common measure used in studies examining the link between economic conditions and health outcomes in the US. We note, however, that nearly all other studies using BLS unemployment rates to study economic conditions and health outcomes conduct the analysis at the state level. Though even state-level statistics are subject to sampling error, these errors are likely to be greater for county-level statistics. ${ }^{10}$ As such, there is reason to be concerned that estimates using county-level unemployment rates as the measure of economic conditions may be subject to attenuation bias induced by measurement error. Moreover, this source of potential bias can be especially problematic for fixed effects estimators (Griliches 1977 and Griliches and Hausman 1986), as we use in this paper.

For this reason, we also consider employment-to-population ratios, produced by the Bureau of Economic Analysis (BEA), which are arguably less prone to sampling error because they are based solely on administrative data whereas unemployment rate statistics rely on the Current Population Survey to measure the number of individuals who are unemployed. ${ }^{11}$

\footnotetext{
${ }^{10}$ As Angrist and Krueger (1999) explain, random "errors tend to average out in aggregate data."

${ }^{11}$ The BEA calculates employment-to-population ratios using data from the Unemployment Insurance system in addition to a vast array of administrative data sets to improve coverage and reliability. As a few examples of the way the BEA deals with industries that are not fully covered by the UI system, they use data from the the Census of Agriculture to produce county estimates of hired farm employment; data from the Railroad Retirement Board to measure employment in the railroad industry; and data
} 
As described above, we are also interested in the potentially heterogeneous effects of economic conditions facing males and females and neither unemployment rates nor employment-to-population ratios are separately available by gender at the county level. For this reason, we use mass-layoff data produced by the BLS. These data provide the number of males and females involved in mass layoff events, by worker's county of residence and year. In particular, the BLS defines a mass layoff event as a situation in which at least 50 individuals from the same firm claim unemployment insurance in a five-week period. ${ }^{12}$ Our data consists of the number of male and female claimants residing in a particular county involved in such an event in each year. In order to put these data into an informative scale, we create mass-layoffs-to-working-age-population ratios using the working-age (18-64) population in the preceding year as the denominator.

The sample means for these data are displayed in Table 1. On average, children in California live in counties with an annual abuse rate of 323 per 100,000. Approximately half of reported abuse is physical, 20 percent is psychological, and 30 percent is sexual. The average unemployment rate over the sample period (1996 to 2009) is 6.6 percent, though there is substantial variation in economic conditions across counties and time. On average, 0.99 percent of a county's working-age population is involved in a mass layoff in any given year, though the rate is higher for males than females as one would expect given their differing labor force participation rates. The means for race and ethnicity demonstrate that California is a diverse state, as 46 percent of its population are non-Hispanic whites, 7 percent are non-Hispanic black, 35 percent are Hispanic, and 12 percent are some other race and ethnicity. The average county includes approximately 322 individuals employed in law enforcement, 227 individuals employed in primary and secondary education, 137 individuals employed in social services, and 1,188 hospital employees per 100,000 individuals in the population.

from the County Business Patterns to measure employment in private schools and religious organizations. Another notable difference between the BEA measure and the BLS measure is that the BEA measure is a place-of-work measure whereas the BLS measure is a place-of-residence measure, i.e., the BEA measures the number of jobs in a county whereas the BLS measures the number of residents in a county who have jobs.

${ }^{12}$ According to estimates from the BLS National Business Employment Dynamics Database, 71.2 percent of private sector employees in the US worked for firms with 50 or more employees in 2012 (see http://www.bls.gov/bdm/bdmfirmsize.htm). 


\subsection{Empirical Strategy}

Our empirical strategy closely follows in the footsteps of previous researchers that have investigated the causal effects of macroeconomic conditions on health outcomes. In particular, since Ruhm (2000), a standard approach in this literature has been to estimate the effects using area-level panel data and regression models that control for area fixed effects, area-specific trends, and year fixed effects. As such, this approach eliminates both the possibility that the estimates might reflect spurious trends in the aggregate and the possibility that the estimates might reflect fixed or linearly-trending differences across high- and low-unemployment areas. In concrete terms, this "area approach" estimates how health outcomes in an area change from trend over and above changes occurring across all areas when its economic conditions change from trend over and above changes occurring across all areas. The estimates are identified using variation across areas in the timing and severity of changing economic conditions. Assuming that unobservable variables related to the outcome of interest do not deviate from an area's trend when its economic conditions deviate from trend, this approach will uncover the causal effect of local economic conditions.

In order to operationalize this identification strategy to estimate the effect of local economic conditions on rates of abuse, we estimate a regression of the following form:

$$
\text { Abuse }_{c t}=E_{c t} \beta+\alpha_{t}+\alpha_{c}+\theta_{c} t+X_{c t} \lambda+\epsilon_{c t}
$$

where Abuse $_{c t}$ is the natural log of the number of abuse reports per 100,000 children in county $c$ and year $t, E_{c t}$ is a measure (or set of measures) of economic conditions in county $c$ and year $t, \alpha_{t}$ are year fixed effects to capture changes occurring across all counties in each year, $\alpha_{c}$ are county fixed effects to control for time-invariant county characteristics, $\theta_{c} t$ are county-specific time trends to control for linearly-trending county characteristics, $X_{c t}$ captures additional time-varying characteristics of the county, and $\epsilon_{c t}$ is an error term that we allow to be correlated within counties across time. ${ }^{13}$ Estimates are weighted by

\footnotetext{
${ }^{13}$ To avoid dropping county-year observations with zero abuse reports from the analysis we replace zeros with ones before calculating the abuse rate. Results from Poisson and negative binomial regres-
} 
the number of children in each county and year. ${ }^{14}$

As we discussed in the previous section, the major concern with empirical analyses of child abuse is that we only observe abuse that is reported. Though under-reporting implies that our constructed measures of abuse likely understate the true extent of abuse, because $\beta$ identifies percent effects, this aspect of the data will not bias our estimates. That said, the estimates will be biased if changing economic conditions affect the rate at which abuse that occurs is reported. However, we investigate this issue by testing the sensitivity of the estimates to the inclusion of controls for employment in the highestchild-abuse-reporting sectors and find no evidence of such bias.

\subsection{Results: Aggregate Measures of Economic Conditions and Child Abuse}

Figure 1 demonstrates the relationship between statewide unemployment rates and child abuse rates in California. These time series are broadly representative of the overall trends taking place across the US. In particular, overall rates of abuse (Panel A) have steadily and dramatically declined over the sample period, falling from 504 cases per 100,000 children in 1996 to 187 per 100,000 in 2009. Perhaps contrary to our priors, no uptick is evident in the early-2000s recession or the most-recent recession. The time series for physical abuse (Panel B) and sexual abuse (Panel D) similarly reflect a downward trend in abuse that does not relate to macroeconomic conditions. In contrast, rates of reported psychological abuse increased from 1996 to 2000, fell from 2000 to 2006, then increased slightly before falling again. As such, this figure provides perhaps a bit of evidence that psychological abuse is related to macroeconomic conditions but, if anything, suggests that abuse falls in recessions. Figures that detrend the abuse series, shown in Appendix A.1, lead to similar conclusions.

sions are similar to the results from the log-linear specification, although they are sometimes larger in magnitude. This occurs because the count model estimates are somewhat sensitive to the presence of outliers, which usually correspond to relatively small counties. When outliers are excluded, Poisson, negative binomial, and log-linear models produce estimates that are comparable both in magnitude and statistical significance.

${ }^{14}$ Unweighted specifications generate results that are similar in magnitude to our main results. 
As we discussed above, conclusions drawn from time-series evidence are problematic because of the wide variety of confounders at the state (and national) level. For example, statewide changes in the probability that abuse is reported could contribute to the long-run decline shown in Figure 1. As such, the approach described in the previous section, which leverages variation in the timing and severity of economic downturns across different counties in California, is better suited to identifying the causal effect of economic conditions. The estimates based on this approach, which controls for county fixed effects, county-specific trends, and year fixed effects, are the focus of the remainder of this section.

Panel A of Table 2 shows the estimated effect of county unemployment rates on overall rates of child abuse. Column 1, which reports the baseline estimates that do not control for any additional covariates, indicates that there is no significant relationship between local economic conditions and rates of child abuse. Column 2, which adds controls for the racial and ethnic makeup of each county in each year, indicates the same. Columns 3, 4, and 5 sequentially add controls for the share of a county's residents employed in primary and secondary schools, law enforcement, and social services. ${ }^{15}$ These controls aim to address the possibility that rates of reported abuse may change during recessions because of changes in employment in the sectors responsible for most reports of child abuse. That said, the estimated coefficients on these control variables (not shown) suggest that employment in high-reporting sectors is not significantly related to reports of abuse, in either a statistical or economic sense. Moreover, the inclusion of these controls does not influence the main results.

Panels B, C, and D present similar estimates that focus on physical abuse, psychological abuse, and sexual abuse, respectively. These estimates imply that unemployment rates are not significantly related to any category of child abuse.

\footnotetext{
${ }^{15}$ Our regressions include indicator variables to account for the fact that employment in these sectors is sometimes missing. In particular, school employment, social services employment, and hospital employment are missing for 12 percent, 3 percent, and 3 percent of observations, respectively. However, because the data are disproportionately missing for very small counties, we have employment in these sectors at the county-year level for over 99.5 percent of California's population. Additional specifications that omit observations for which employment in any of the four high-reporting sectors is missing are presented in Appendix A.2. Results from these specifications are similar to our main results.
} 
As we discussed in Section 3.1, there is reason to be concerned that estimates using county unemployment rates as the measure of local economic conditions might be subject to measurement-error-induced attenuation bias. Motivated by the notion that employment is better measured than unemployment, Table 3 instead considers employmentto-population ratios as the measure of economic conditions. In all specifications, the estimates continue to suggest that economic conditions are not significantly related to abuse.

\subsection{Results: Gender-specific Measures of Economic Conditions}

As we discussed in Section 1, there are several reasons to believe that economic conditions facing males and changing economic conditions facing females may have different, possibly opposite-signed, effects. In order to explore this issue, we must turn to an alternative source of data because neither gender-specific unemployment rates nor gender-specific employment-to-population ratios are available at the county level. For this reason, we use mass-layoff-to-population ratios constructed from mass layoff data produced by the Bureau of Labor Statistics who provided separate counts by gender.

Though used less often than either unemployment or employment rates as a proxy for economic conditions, mass layoff statistics have the advantage in this setting that they reflect sudden and relatively unexpected outflows from employment resulting from changes in labor demand rather than supply-driven movements in and out of the labor force. ${ }^{16}$ Relative to other economic indicators, the effects of mass layoffs also are likely to be concentrated at the lower end of the labor force skill distribution, disproportionately affecting the segment of the population most likely to be involved in child abuse reports. As such, it is possible that mass layoffs may have significant effects on abuse rates, even if overall unemployment and employment rates are uncorrelated with abuse. For comparison with the earlier results that are based on more-conventional measures of economic conditions, we first present estimates that consider mass layoffs overall in Table

\footnotetext{
${ }^{16}$ Because they pick up only entry into unemployment and are unlikely to be affected by changes in labor force participation and the average duration of unemployment over the course of the cycle, mass layoff rates tend to lead unemployment rates, peaking at the beginning of an economic downturn, then returning to trend long before unemployment rates fall to pre-recession levels.
} 
4. These estimates again indicate that overall measures of economic conditions are not significantly related to child abuse. ${ }^{17}$

Panel A of Table 5 presents our main results. As before, the estimates control for county fixed effects, county-specific trends, and year fixed effects. However, instead of using a single measure of county economic conditions, we use separate measures that capture the potentially-different economic conditions facing males and females: male mass-layoff-to-population ratios and female mass-layoff-to-population ratios. These two variables separately tabulate the number of males and females residing in each county that are involved in mass layoff events in a given year as a share of the number of working-age individuals of the same gender residing in the county the prior year.

Because any mass layoff event involving both male and female workers will show up in both series, there is a degree of co-movement in the two variables that cannot contribute to the identification of our coefficients of interest. However, there also exists significant independent variation in the two series, illustrated by the scatter plots in Appendix Figure A2, that we posit is driven by differences across counties and over time in the gender composition of declining industries. The intuition is straightforward: when male-dominated industries like manufacturing or construction experience downturns, the associated layoffs disproportionately affect men, while mass-layoff events at call centers, retail-sales firms, or firms in health administration will disproportionately affect female employment, as females make up a relatively large share of the workers in those industries. ${ }^{18}$ Recent discussions of the dramatic relative decline in labor market conditions for males in the Great Recession and its link to differences between males and females in the industry-composition of their employment in Hoynes, Miller, and Schaller (2012) and Sahin, Song, and Hobijn (2010) support this perspective. ${ }^{19}$

\footnotetext{
${ }^{17}$ To address the concern that variation in the population denominator is driving our results, we have considered an alternative specification that includes layoffs in levels. These results are qualitatively similar to our main results.

${ }^{18}$ In 2011, industries in which more than half of individuals claiming unemployment insurance as a result of mass layoffs were female included: retail trade, transportation and warehousing, finance and insurance, educational services, health care and social assistance, accommodation and food services, and other services. Administrative and waste services, retail trade, and accommodation and food services were among the industries with the largest share of claimants overall, ranking 3, 4, and 5 out of 19 industry classifications (U.S. Bureau of Labor Statistics (2012)).

${ }^{19}$ Sahin, Song, and Hobijn (2010) summarize their findings succinctly: "In the 2007 recession, men
} 
The results based on our gender-specific approach are in stark contrast to the results focusing on more-aggregate measures of economic conditions. Whereas none of the standard measures of overall economic conditions are significantly related to child abuse, the estimated effects of both male and female mass-layoff-to-population ratios are highly significant. Moreover, they have different signs, which explains why the effects were masked in prior analyses. The estimates indicate that male layoffs increase abuse whereas female layoffs reduce abuse. In particular, the point estimates imply that a 0.1 percentage-point increase in the fraction of working-age males being laid off leads to a 3.09 percent increase in the number of reports of abuse. In contrast, the point estimates imply that 0.1 percentage-point increase in the fraction of working-age females being laid off leads to a 3.27 percent reduction in the number of reports of abuse.

Panels B, C, and D of Table 5 demonstrate that the overall effects on child abuse are not driven by any single category of abuse. The estimates imply that male layoffs increase the incidence of physical abuse, psychological abuse, and sexual abuse, while female layoffs decrease the incidence of physical abuse, psychological abuse, and sexual abuse. That said, sexual abuse appears to be less responsive to changing economic conditions than other categories of abuse.

\section{Discussion of Potential Mechanisms}

There are a wide variety of mechanisms through which economic conditions might affect child abuse. We will discuss several such mechanisms in this section, beginning with an extensive consideration of the link between parental employment and time with children.

experienced a much greater increase in their flow rate from employment to unemployment than did women. In fact, the male EU flow rate at the peak of the gender gap was almost 70 percent higher than the female rate. This disparity can be traced in large part to the sectoral composition of job losses specifically, the fact that job losses have been highly concentrated in the goods-producing industries of manufacturing and construction, which generally employ a higher proportion of male workers." 


\subsection{Parental Employment and Time With Children}

A theoretical framework that builds on family-time-use models (such as Lundberg (1985), Killingsworth and Heckman (1987), and Stephens (2002)) and acknowledges differential risks associated with a child's time spent with different caregivers can explain our main results as follows. Male layoffs cause children to spend more time with fathers, which causes abuse to rise because fathers have a higher propensity to abuse children than mothers and other childcare providers. Female layoffs cause children to spend less time with fathers, which causes abuse to fall. ${ }^{20}$

Of course, whether this explanation is compelling depends on the extent to which parental employment actually relates to parental time use in such a manner. In particular, if this mechanism is truly at work, then we should observe that fathers spend less time with children when they are employed and more time with children when their spouses are employed. Similarly, we should observe that mothers spend less time with children when they are employed and more time with children when their spouses are employed. We test these predictions using repeated cross-sections of the American Time Use Survey (ATUS) from 2003 to $2011 .^{21}$

The ATUS provides information on the activities that an individual performed during a 24-hour period. ${ }^{22}$ Moreover, the ATUS asks who else was around during each activity. As such, we can separately consider time spent with children around, time spent with

\footnotetext{
${ }^{20}$ We forgo presenting a formal the theoretical model along these lines in this paper because the value added would be negligible. Prior theoretical models have established that both own employment status and partner's employment status are likely to affect an individual's time use. In particular, familytime-use models suggest that a worker who is laid off will increase time in non-market activities (e.g., childcare, leisure, or, more generally, "home production") while his or her partner increases time spent in the labor market to make up for the lost household income. The point we make here is simply that such changes in time allocation may have mechanical effects on child abuse.

${ }^{21}$ In related work, both Fox, Han, Ruhm, and Waldfogel (2012) and Colman and Dave (2011) are informative about the effects of parental employment and time spent with children. In particular, Fox et al. (forthcoming) demonstrate that parents working full time spend less time than nonworking parents in primary childcare activities. And Colman and Dave (2011) demonstrate that own-gendered employment rates (at the state level) are associated with less time in childcare and opposite-gender employment rates are associated with more time in childcare. For our purposes, however, it is important to separately consider males and females. In addition, we want to consider broader measures of time spent with children since abuse can occur while parents are together with children outside of primary childcare activities. This is an especially important consideration given that time spent performing primary childcare activities represents only 20 percent of father's time spent with children and only 28 percent of mother's time spent with children.

${ }^{22}$ We omit from the sample time-use surveys that correspond to holidays.
} 
children around but no spouse around, and time spent performing childcare activities. All of these measures are meant to serve as proxies for childcare responsibilities. For our purposes, we focus on surveyed individuals who are currently living with a spouse or partner in a household with a child under age 18. This restriction leads to a sample of approximately 13,000 fathers and 15,000 mothers. Notably, the fathers and mothers in the sample come from different households because the ATUS only surveys one individual per household.

Our analysis considers how own employment status and spouse's employment status relate to the amount of time that an individual spends with children. ${ }^{23}$ At the same time, we acknowledge that neither own employment status nor spouse's employment status are exogenous. A nice feature of the ATUS that will help us to mitigate omitted variable bias is the fact that the ATUS sample is drawn from individuals surveyed in the Current Population Survey (CPS) and is conducted two-to-five months following the CPS. This feature of the data allows us to control flexibly for the economic circumstances of the family a few months prior to the time-use survey. In our richest specification, we control for the triple interaction of the individual's employment status in the CPS survey, the spouse's employment status in the CPS survey, and the income category for their annual family income reported in the CPS survey. ${ }^{24}$ As such, we estimate the change in time use associated with changes in employment status within groups of individuals who recently had very similar economic circumstances.

Table 6 separately reports means for the sample of fathers and the sample of mothers. These statistics demonstrate the dramatic difference in mothers' and fathers' time spent with children. On average, mothers spend 385 minutes per day with children whereas fathers spend 251 minutes with children; mothers spend 229 minutes of alone time with children whereas fathers spend 87 minutes of alone time with children; and mothers spend 109 minutes in primary childcare whereas fathers spend 54 minutes in primary childcare. These statistics also highlight the fact that primary childcare activities represent only a

\footnotetext{
${ }^{23}$ Note that the ATUS does not distinguish between individuals who are unemployed and individuals who are not in the labor force.

${ }^{24}$ The ATUS provides incomes in 16 different categories.
} 
small share of parental time with children.

Columns 1 through 3 of Table 7 focus on a father's time with children as a function of his own employment status and his spouse's employment status. Each of these columns control for survey year fixed effects and day of week fixed effects. Column 2 additionally controls for a rich set of demographic characteristics for the individual and his spouse. ${ }^{25}$ Column 3 presents estimates from our preferred specification which controls flexibly for the economic circumstances of the family a few months prior to the time-use survey. ${ }^{26}$ Columns 4 through 6 are structured similarly but instead focus on a mother's time with children as a function of her own employment status and her spouse's employment status. Panels A, B, and C separately consider time spent with children, time spent alone with children, and time spent in primary childcare activities.

As one would expect, estimates consistently indicate that non-employment is associated with more time spent with children, for both fathers and mothers. Moreover, consistent with models of family time use, the estimates also demonstrate that having a spouse who is not employed is associated with less time spent with children. Notably, all prior studies that have considered the extent to which there are "added worker effects" have focused on the labor supply of wives since working-age men tend to be very strongly attached to the labor market and, thus, may have little scope to change their allocation of time between market work and home production. That said, while women's time spent with children is much more sensitive to their spouses' employment status than men's time spent with children, our estimates suggest that men's time spent with children is affected by their wives' employment status. In particular, the estimates indicate that having a wife who is not employed is associated with 29 percent more time alone with children. ${ }^{27}$

\footnotetext{
${ }^{25}$ Specifically, this column controls for age fixed effects, spouse's age fixed effects, educational attainment (less than high school, exactly high school, some college, or four-or-more years of college) fixed effects, spouse's educational attainment fixed effects, race (white, black, or other) and ethnicity (Hispanic or non-Hispanic) fixed effects, spouse's race and ethnicity fixed effects, state fixed effects, age of youngest child fixed effects, and household size fixed effects.

${ }^{26}$ Specifically, this column controls for the triple interaction of the individual's employment status, spouse's employment status, and prior year family income at the time of the CPS, in addition to fixed effects for the industry, occupation, and hours usually worked for the individual and the spouse (with additional categories created for these variables for those who were not working at the time of the CPS).

${ }^{27}$ To better match the variation used in our analysis of child abuse, we have also estimated specifications focusing solely on variation induced by transitions out of employment by omitting from the sample any families in which an individual or an individual's spouse transitions into employment between the
} 
Overall, these results support the idea that the distribution of childcare may be a key mechanism linking economic conditions and child abuse. They suggest that a father's layoff would lead children to spend more time with fathers and less time with mothers, while a mother's layoff would lead children to spend less time alone with fathers and more time with mothers. Although we have tried to address potential confounders with a model that controls for a rich set of covariates, we cannot rule out the possibility that other unobservables may be contributing to the estimates. As such, we think of these estimates as "proof of concept" that the impacts of male and female layoffs on child abuse documented in Section 3.4 can be explained by their impacts on childcare.

\subsection{Other Potential Mechanisms}

Though our discussion thus far has emphasized parental time use and the differential risks associated with children's time spent with fathers and mothers, other mechanisms may contribute to the estimated effects of economic conditions on child abuse. In particular, many factors associated with layoffs may have direct impacts on individuals' propensity to abuse children, and it is possible that the role of these factors may differ by gender. However, in order to explain the gender asymmetry in the effects of layoffs, particularly the strong reduction in abuse associated with female layoffs, we believe that these effects would have to follow unlikely patterns. Along these lines, in this section we discuss why explanations emphasizing mental health, family structure, and household bargaining are not very convincing.

Mental health is a natural mechanism that might link economic conditions and abuse. In particular, if deteriorating mental health increases an individual's propensity to abuse, then effects of economic conditions on mental health should generate corresponding effects on abuse rates. While it is possible that male layoffs may have greater impacts on mental health than female layoffs (perhaps due to larger shocks to family income), there is no evidence to suggest that female layoffs reduce household stress. In fact, the existing

Current Population Survey and the American Time Use Survey. In addition, we have examined the relationship between parental employment and time spent with children in non-traditional families, including households with unmarried partners, step-children, and foster children. Results from these analyses, shown in Appendix A.2, are similar to our main estimates. 
literature suggests that both male and female layoffs have significant effects on smoking (Black, Devereux, and Salvanes 2012), suicide (Eliason and Storrie 2009a) and alcohol abuse (Eliason and Storrie 2009b).

Family structure is another appealing mechanism to consider given the large amount of evidence that job loss increases the incidence of divorce (Charles and Stephens Jr 2004, Eliason 2012, Doiron and Mendolia 2011). However, because both male and female layoffs increase the incidence of divorce (Charles and Stephens Jr 2004, Eliason 2012), this mechanism is unlikely to explain the asymmetric effects we find.

Motivated by Aizer (2010), we might think that the link between economic conditions and abuse is driven by changes in household bargaining power. In particular, Aizer (2010) finds that increases in female wages relative to male wages reduces domestic violence against females. Since females are usually the primary caregivers, we might expect child abuse to follow a similar pattern. That is, this view of the household would lead us to expect male layoffs to increase women's bargaining power and thus to reduce child abuse and to expect female layoffs to decrease women's bargaining power and thus to increase abuse. However, we find the opposite of these predictions.

Finally, we might think that economic conditions affect reported abuse through impacts on the rate at which abuse is reported. Though we have taken steps to address this potential source of bias empirically by controlling for employment in the highestreporting sectors, we can never be sure that it has been fully addressed. That said, it is hard to imagine how male layoffs would increase the rate at which abuse is reported and female layoffs would reduce the rate at which abuse is reported, especially when we have controlled for employment in the highest-reporting sectors.

In summary, though some of these other mechanisms may play a role in the link between economic conditions and child abuse, we think they are unlikely to play as large a role as parental time use, which provides a straightforward explanation for our main results when one considers the differential risks associated with children's time spent with different childcare providers. 


\section{Conclusion}

In this paper, we have explained why overall measures of economic conditions are not strongly related to child abuse. They mask opposing effects of economic conditions facing males and females. On average, economic downturns do not have a significant effect on child abuse. However, downturns that disproportionately affect men increase abuse whereas downturns that disproportionately affect females reduce abuse. An overarching lesson from this study is that we should not think about "income" in the context of child abuse without considering its source. Moreover, the distribution of childcare appears to be a first-order mechanism that needs to be considered in analyses of child abuse.

We view this work as a first step towards thinking about the link between economic conditions and child abuse in a new way, acknowledging that much work remains to be done on the topic. In addition to bringing new data sources to bear on the research question, it will be important for future work to consider differential impacts on abuse committed by mothers and fathers and to examine whether the effects are disproportionate for any particular groups of children. 


\section{References}

Aizer, A. (2010): "The gender wage gap and domestic violence," American Economic Review, 100(4), 1847.

Angrist, J., And A. KRueger (1999): "Empirical strategies in labor economics," Handbook of Labor Economics, 3, 1277-1366.

Bertrand, M. (2011): "New Perspectives on Gender," Handbook of Labor Economics, $4,1543-1590$.

Bitler, M., And M. Zavodny (2002): "Child abuse and abortion availability," American Economic Review, pp. 363-367.

(2004): "Child maltreatment, abortion availability, and economic conditions," Review of Economics of the Household, 2(2), 119-141.

Black, S. E., P. J. Devereux, and K. G. Salvanes (2012): "Losing Heart? The Effect of Job Displacement on Health," NBER Working Paper.

Blau, F., L. Kahn, and J. Waldfogel (2000): "Understanding Young Women's Marriage Decisions: The Role of Labor and Marriage Market Conditions," Industrial and Labor Relations Review, pp. 624-647.

Charles, K., And M. Stephens Jr (2004): "Job Displacement, Disability, and Divorce," Journal of Labor Economics, 22(2), 489-522.

Colman, G., And D. Dave (2011): "Exercise, physical activity, and exertion over the business cycle," NBER Working Paper.

Coulton, C., J. Korbin, M. Su, ET Al. (1999): "Neighborhoods and child maltreatment: a multi-level study," Child Abuse \& Neglect, 23(11), 1019.

Currie, J., And E. Tekin (2012): "Understanding the Cycle Childhood Maltreatment and Future Crime," Journal of Human Resources, 47(2), 509-549.

Currie, J., And C. Widom (2010): "Long-term consequences of child abuse and neglect on adult economic well-being," Child Maltreatment, 15(2), 111-120.

Doiron, D., And S. Mendolia (2011): "The impact of job loss on family dissolution," Journal of Population Economics, 25(1), 367-398.

Dubowitz, H., ET AL. (2006): "Where's Dad? A need to understand father's role in child maltreatment," Child Abuse $\&$ Neglect, 30(5), 461-465.

Eliason, M. (2012): "Lost jobs, broken marriages," Journal of Population Economics, pp. 1-33.

Eliason, M., and D. Storrie (2009a): "Does job loss shorten life?," Journal of Human Resources, 44(2), 277-302.

(2009b): "Job loss is bad for your health-Swedish evidence on cause-specific hospitalization following involuntary job loss," Social Science $\mathscr{E}$ Medicine, 68(8), 13961406. 
Fletcher, J. (2009): "Childhood mistreatment and adolescent and young adult depression," Social Science $\&$ Medicine, 68(5), 799-806.

Fox, L., W.-J. Han, C. Ruhm, and J. Waldfogel (2012): "Time for Children: Trends in the Employment Patterns of Parents, 1967-2009," Demography, pp. 1-25.

Francis, K., And D. Wolfe (2008): "Cognitive and emotional differences between abusive and non-abusive fathers," Child Abuse \& Neglect, 32(12), 1127-1137.

Garbarino, J. (1976): "A preliminary study of some ecological correlates of child abuse: The impact of socioeconomic stress on mothers," Child Development, pp. 178-185.

Garbarino, J., and K. Kostelny (1992): "Child maltreatment as a community problem," Child Abuse \& Neglect, 16(4), 455-464.

Gelles, R. (1992): "Poverty and Violence Toward Children," American Behavioral Scientist, 5(3), 258-274.

GIL, D. (1970): Violence against children: Physical child abuse in the United States. Harvard University Press Cambridge, MA.

Gillham, B., G. Tanner, B. Cheyne, I. Freeman, M. Rooney, and A. Lambie (1998): "Unemployment rates, single parent density, and indices of child poverty: their relationship to different categories of child abuse and neglect," Child Abuse \& Neglect, 22(2), 79-90.

Griliches, Z. (1977): "Estimating the returns to schooling: Some econometric problems," Econometrica, pp. 1-22.

Griliches, Z., AND J. Hausman (1986): "Errors in variables in panel data," Journal of Econometrics, 31(1), 93-118.

Guterman, N., And Y. LeE (2005): "The role of fathers in risk for physical child abuse and neglect: Possible pathways and unanswered questions," Child Maltreatment, 10(2), $136-149$.

Hoynes, H., D. Miller, And J. Schaller (2012): "Who Suffers During Recessions?," The Journal of Economic Perspectives, 26(3), 27-47.

Killingsworth, M. R., and J. J. Heckman (1987): "Female labor supply: A survey," in Handbook of Labor Economics, ed. by O. Ashenfelter, and R. Layard, vol. 1, chap. 2, pp. 103-204. Elsevier.

Lee, S., J. Bellamy, and N. Guterman (2009): "Fathers, Physical Child Abuse, and Neglect Advancing the Knowledge Base," Child Maltreatment, 14(3), 227-231.

Light, R. (1973): "Abused and neglected children in America: A study of alternative policies," Harvard Educational Review, 43(4), 556-598.

LundBerg, S. (1985): "The Added Worker Effect," Journal of Labor Economics, 3(1), $11-37$.

Paxson, C., And J. Waldfogel (1999): "Parental resources and child abuse and neglect," The American Economic Review, 89(2), 239-244. 
(2002): "Work, Welfare, and Child Maltreatment," Journal of Labor Economics, $20(3), 435-474$.

QIAn, N. (2008): "Missing women and the price of tea in China: The effect of sex-specific earnings on sex imbalance," The Quarterly Journal of Economics, 123(3), 1251-1285.

Ruhm, C. (2000): "Are recessions good for your health?," The Quarterly Journal of Economics, 115(2), 617-650.

Sahin, A., J. Song, And B. HobiJn (2010): "The unemployment gender gap during the 2007 recession," Current Issues in Economics and Finance, 16(2).

Schaller, J. (2012): "Booms, busts, and fertility: Testing the Becker model using gender-specific labor demand," University of Arizona Working Paper.

Sedlak, A., J. Mettenburg, M. Basena, I. Peta, K. McPherson, A. Greene, ET AL. (2010): "Fourth national incidence study of child abuse and neglect (NIS-4)," US Department of Health and Human Services.

SEIGlie, C. (2004): "Understanding child outcomes: An application to child abuse and neglect," Review of Economics of the Household, 2(2), 143-160.

Steinberg, L., R. Catalano, and D. Dooley (1981): "Economic antecedents of child abuse and neglect," Child Development, pp. 975-985.

Stephens, M. (2002): "Worker Displacement and the Added Worker Effect," Journal of Labor Economics, 20(3), 504-537.

Thornberry, T., K. Henry, T. Ireland, and C. Smith (2010): "The causal impact of childhood-limited maltreatment and adolescent maltreatment on early adult adjustment," Journal of Adolescent Health, 46(4), 359-365.

U.S. Bureau of Labor Statistics (2012): "Extended Mass Layoffs in 2011 (Report 1039)," .

U.S. Department of Health and Human Services (2011): "Child Maltreatment 2010," .

Waldfogel, J. (1998): "Child Welfare Research: How Adequate are the Data?," Children and Youth Services Review, 22(9), 705-741.

Wood, J., S. Medina, C. Feudtner, X. Luan, R. Localio, E. Fieldston, and D. Rubin (2012): "Local Macroeconomic Trends and Hospital Admissions for Child Abuse, 2000-2009," Pediatrics, 130(2), e358-e364.

ZIELINSKI, D. (2009): "Child maltreatment and adult socioeconomic well-being," Child Abuse \& Neglect, 33(10), 666-678. 
Figure 1

Unemployment Rates and Child Abuse Reports in California, 1996-2009

Panel A: All Abuse

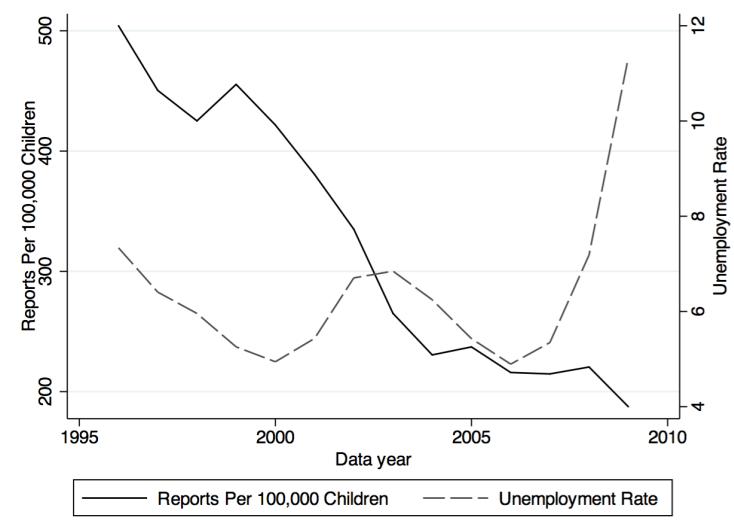

Panel C: Psychological Abuse

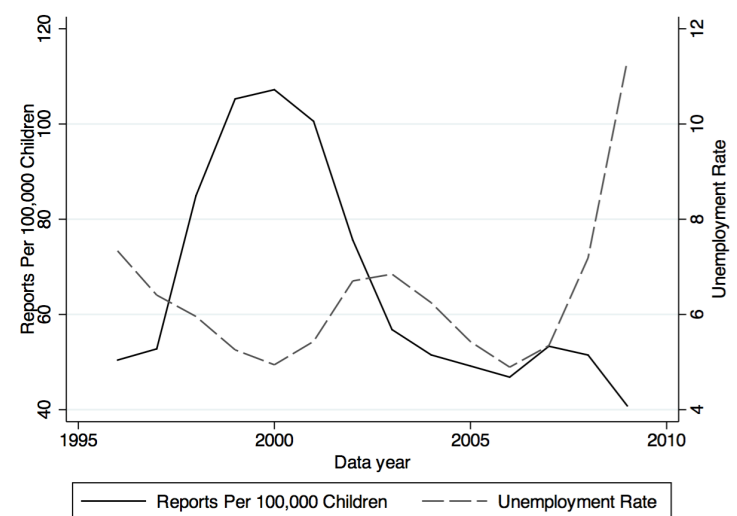

Panel B: Physical Abuse

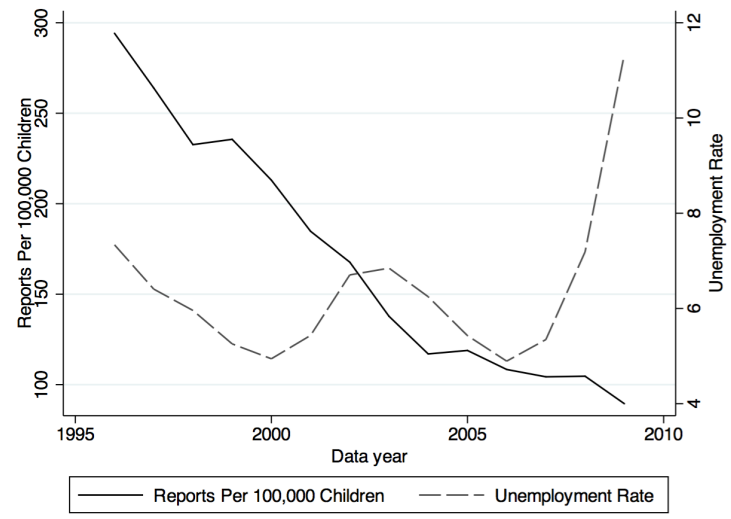

Panel D: Sexual Abuse

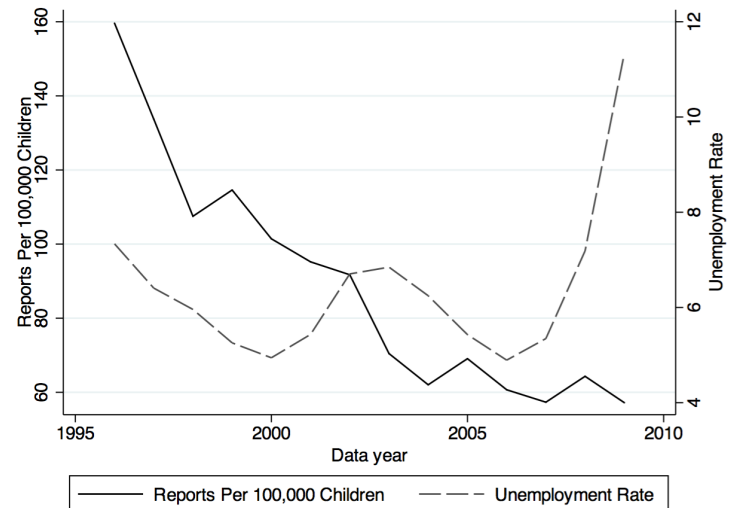

Notes: The number of reports per 100,000 children are calculated using California Department of Justice data on reports and population data from the National Cancer Institute's Surveillance Epidemiology and End Results program. Unemployment rates are based on data from the Bureau of Labor Statistics. 
Table 1

Sample Means for Abuse, Economic Conditions, and Demographics in California

\begin{tabular}{lc}
\hline Abuse Rate (Per 100,000 Children) & 323.73 \\
Physical Abuse Rate (Per 100,000 Children) & 169.18 \\
Mental Abuse Rate (Per 100,000 Children) & 66.69 \\
Sexual Abuse Rate (Per 100,000 Children) & 89.12 \\
Unemployment Rate & 6.63 \\
Employment-to-Population Ratio & 55.03 \\
Mass-Layoffs-to-Population Ratio & 0.99 \\
Male Mass-Layoffs-to-Population Ratio & 1.11 \\
Female Mass-Layoffs-to-Population Ratio & 0.87 \\
Fraction of County White & 0.46 \\
Fraction of County Black & 0.07 \\
Fraction of County Other Race & 0.12 \\
Fraction of County Hispanic & 0.35 \\
School Employment (Per 100,000) & 227.05 \\
Police Employment (Per 100,000) & 322.97 \\
Social Services Employment (Per 100,000) & 137.45 \\
Hospital Employment (Per 100,000) & 1188.24 \\
\hline
\end{tabular}

Notes: The sample includes 812 county-year observations for 58 California counties from 1996 to 2009. Sample means are weighted by the number of children in each county in each county and year. Abuse rates are calculated using California Department of Justice data on reports and population data from the National Cancer Institute's Surveillance Epidemiology and End Results program. Unemployment rates are based on data from the Bureau of Labor Statistics. Employment-to-population ratios are based on data from the Bureau of Economic Analysis. Mass-layoffs-to-population ratios are constructed using mass layoff data from the Bureau of Labor Statistics and the working-age population in the previous year. The fraction of individuals in race and ethnic groups are based on population data from the National Cancer Institute's Surveillance Epidemiology and End Results program. School employment, social services employment, and hospital employment are based on County Business Patterns Data. Social services employment, i.e., the number of individuals working in social services, are also based on County Business Patterns data. Police employment data are from the Uniform Crime Reports' Police Employee (LEOKA) Database. 
Table 2

Unemployment Rates and Child Abuse Reports in California

\begin{tabular}{|c|c|c|c|c|c|c|}
\hline & $(1)$ & $(2)$ & (3) & $(4)$ & $(5)$ & $(6)$ \\
\hline \multicolumn{7}{|l|}{ Panel A: All Types of Abuse } \\
\hline Unemployment Rate & $\begin{array}{c}0.010 \\
(0.037)\end{array}$ & $\begin{array}{c}0.005 \\
(0.040)\end{array}$ & $\begin{array}{c}0.005 \\
(0.040)\end{array}$ & $\begin{array}{c}0.005 \\
(0.040)\end{array}$ & $\begin{array}{c}0.005 \\
(0.040)\end{array}$ & $\begin{array}{c}0.004 \\
(0.040)\end{array}$ \\
\hline Demographic Controls & no & yes & yes & yes & yes & yes \\
\hline School Employment Controls & no & no & yes & yes & yes & yes \\
\hline Police Employment Controls & no & no & no & yes & yes & yes \\
\hline Social Services Employment Controls & no & no & no & no & yes & yes \\
\hline Hospital Employment Controls & no & no & no & no & no & yes \\
\hline \multicolumn{7}{|l|}{ Panel B: Physical Abuse } \\
\hline Unemployment Rate & $\begin{array}{l}-0.008 \\
(0.039)\end{array}$ & $\begin{array}{c}0.004 \\
(0.043)\end{array}$ & $\begin{array}{c}0.004 \\
(0.043)\end{array}$ & $\begin{array}{c}0.004 \\
(0.043)\end{array}$ & $\begin{array}{c}0.004 \\
(0.043)\end{array}$ & $\begin{array}{c}0.003 \\
(0.043)\end{array}$ \\
\hline Demographic Controls & no & yes & yes & yes & yes & yes \\
\hline School Employment Controls & no & no & yes & yes & yes & yes \\
\hline Police Employment Controls & no & no & no & yes & yes & yes \\
\hline Social Services Employment Controls & no & no & no & no & yes & yes \\
\hline Hospital Employment Controls & no & no & no & no & no & yes \\
\hline \multicolumn{7}{|l|}{ Panel C: Psychological Abuse } \\
\hline Unemployment Rate & $\begin{array}{l}-0.059 \\
(0.051)\end{array}$ & $\begin{array}{l}-0.030 \\
(0.057)\end{array}$ & $\begin{array}{l}-0.030 \\
(0.056)\end{array}$ & $\begin{array}{l}-0.029 \\
(0.056)\end{array}$ & $\begin{array}{c}-0.031 \\
(0.054)\end{array}$ & $\begin{array}{l}-0.030 \\
(0.055)\end{array}$ \\
\hline Demographic Controls & no & yes & yes & yes & yes & yes \\
\hline School Employment Controls & no & no & yes & yes & yes & yes \\
\hline Police Employment Controls & no & no & no & yes & yes & yes \\
\hline Social Services Employment Controls & no & no & no & no & yes & yes \\
\hline Hospital Employment Controls & no & no & no & no & no & yes \\
\hline \multicolumn{7}{|l|}{ Panel D: Sexual Abuse } \\
\hline Unemployment Rate & $\begin{array}{c}0.056 \\
(0.066)\end{array}$ & $\begin{array}{c}0.009 \\
(0.039)\end{array}$ & $\begin{array}{c}0.009 \\
(0.039)\end{array}$ & $\begin{array}{c}0.009 \\
(0.039)\end{array}$ & $\begin{array}{c}0.009 \\
(0.039)\end{array}$ & $\begin{array}{c}0.007 \\
(0.039)\end{array}$ \\
\hline Demographic Controls & no & yes & yes & yes & yes & yes \\
\hline School Employment Controls & no & no & yes & yes & yes & yes \\
\hline Police Employment Controls & no & no & no & yes & yes & yes \\
\hline Social Services Employment Controls & no & no & no & no & yes & yes \\
\hline Hospital Employment Controls & no & no & no & no & no & yes \\
\hline
\end{tabular}

Notes: The sample includes 812 county-year observations for 58 California counties from 1996 to 2009 . The dependent variable is the $\log$ of the number of reports per 100,000 children - these are calculated using California Department of Justice data on reports and population data from the National Cancer Institute's Surveillance Epidemiology and End Results program. Unemployment rates are based on data from the Bureau of Labor Statistics. All estimates based on regression models that include year fixed effects, county fixed effects, and county-specific trends. The estimates are weighted by the number of children in each county in each year. Demographic controls include the fraction of residents who are black, the fraction of residents who are Hispanic, and the fraction of residents who are neither black nor Hispanic. Controls for school, police, social services, and hospital employment include the level of employment per capita and an indicator variable to control for cases with a missing value. School employment, social services employment, and hospital employment are based on County Business Patterns Data while police employment data are from the Uniform Crime Reports' Police Employee (LEOKA) Database. Robust standard errors, clustered on counties, are in parentheses.

Significance at $1 \%, 5 \%, 10 \%$ levels are indicated by $* * *, * *$, and $*$, respectively. 
Table 3

Employment-to-Population Ratios and Child Abuse Reports in California

\begin{tabular}{|c|c|c|c|c|c|c|}
\hline & (1) & $(2)$ & $(3)$ & $(4)$ & (5) & (6) \\
\hline \multicolumn{7}{|l|}{ Panel A: All Types of Abuse } \\
\hline Employment-to-Population Ratio & $\begin{array}{c}0.014 \\
(0.037)\end{array}$ & $\begin{array}{c}-0.008 \\
(0.029)\end{array}$ & $\begin{array}{c}-0.009 \\
(0.029)\end{array}$ & $\begin{array}{c}-0.010 \\
(0.029)\end{array}$ & $\begin{array}{c}-0.009 \\
(0.029)\end{array}$ & $\begin{array}{c}-0.008 \\
(0.029)\end{array}$ \\
\hline Demographic Controls & no & yes & yes & yes & yes & yes \\
\hline School Employment Controls & no & no & yes & yes & yes & yes \\
\hline Police Employment Controls & no & no & no & yes & yes & yes \\
\hline Social Services Employment Controls & no & no & no & no & yes & yes \\
\hline Hospital Employment Controls & no & no & no & no & no & yes \\
\hline \multicolumn{7}{|l|}{ Panel B: Physical Abuse } \\
\hline Employment-to-Population Ratio & $\begin{array}{c}0.026 \\
(0.038)\end{array}$ & $\begin{array}{c}-0.005 \\
(0.030)\end{array}$ & $\begin{array}{c}-0.007 \\
(0.030)\end{array}$ & $\begin{array}{l}-0.007 \\
(0.030)\end{array}$ & $\begin{array}{l}-0.007 \\
(0.031)\end{array}$ & $\begin{array}{c}-0.006 \\
(0.031)\end{array}$ \\
\hline Demographic Controls & no & yes & yes & yes & yes & yes \\
\hline School Employment Controls & no & no & yes & yes & yes & yes \\
\hline Police Employment Controls & no & no & no & yes & yes & yes \\
\hline Social Services Employment Controls & no & no & no & no & yes & yes \\
\hline Hospital Employment Controls & no & no & no & no & no & yes \\
\hline \multicolumn{7}{|l|}{ Panel C: Psychological Abuse } \\
\hline Employment-to-Population Ratio & $\begin{array}{c}0.019 \\
(0.042)\end{array}$ & $\begin{array}{c}0.001 \\
(0.043)\end{array}$ & $\begin{array}{c}-0.003 \\
(0.042)\end{array}$ & $\begin{array}{c}-0.001 \\
(0.042)\end{array}$ & $\begin{array}{c}-0.002 \\
(0.042)\end{array}$ & $\begin{array}{c}-0.003 \\
(0.042)\end{array}$ \\
\hline Demographic Controls & no & yes & yes & yes & yes & yes \\
\hline School Employment Controls & no & no & yes & yes & yes & yes \\
\hline Police Employment Controls & no & no & no & yes & yes & yes \\
\hline Social Services Employment Controls & no & no & no & no & yes & yes \\
\hline Hospital Employment Controls & no & no & no & no & no & yes \\
\hline \multicolumn{7}{|l|}{ Panel D: Sexual Abuse } \\
\hline Employment-to-Population Ratio & $\begin{array}{c}-0.012 \\
(0.035)\end{array}$ & $\begin{array}{c}-0.025 \\
(0.025)\end{array}$ & $\begin{array}{c}-0.025 \\
(0.026)\end{array}$ & $\begin{array}{c}-0.026 \\
(0.026)\end{array}$ & $\begin{array}{c}-0.025 \\
(0.026)\end{array}$ & $\begin{array}{c}-0.024 \\
(0.026)\end{array}$ \\
\hline Demographic Controls & no & yes & yes & yes & yes & yes \\
\hline School Employment Controls & no & no & yes & yes & yes & yes \\
\hline Police Employment Controls & no & no & no & yes & yes & yes \\
\hline Social Services Employment Controls & no & no & no & no & yes & yes \\
\hline Hospital Employment Controls & no & no & no & no & no & yes \\
\hline
\end{tabular}

Notes: The sample includes 812 county-year observations for 58 California counties from 1996 to 2009 . The dependent variable is the $\log$ of the number of reports per 100,000 children - these are calculated using California Department of Justice data on reports and population data from the National Cancer Institute's Surveillance Epidemiology and End Results program. Employment-to-population ratios are based on data from the Bureau of Economic Analysis. All estimates based on regression models that include year fixed effects, county fixed effects, and county-specific trends. The estimates are weighted by the number of children in each county in each year. Demographic controls include the fraction of residents who are black, the fraction of residents who are Hispanic, and the fraction of residents who are neither black nor Hispanic. Controls for school, police, social services, and hospital employment include the level of employment per capita and an indicator variable to control for cases with a missing value. School employment, social services employment, and hospital employment are based on County Business Patterns Data while police employment data are from the Uniform Crime Reports' Police Employee (LEOKA) Database. Robust standard errors, clustered on counties, are in parentheses. Significance at $1 \%, 5 \%, 10 \%$ levels are indicated by $* * *, * *$, and ${ }^{*}$, respectively. 
Table 4

Mass-Layoff-to-Population Ratios and Child Abuse Reports in California

\begin{tabular}{|c|c|c|c|c|c|c|}
\hline & (1) & $(2)$ & $(3)$ & $(4)$ & $(5)$ & (6) \\
\hline \multicolumn{7}{|l|}{ Panel A: All Types of Abuse } \\
\hline Mass-Layoffs-to-Population Ratio & $\begin{array}{c}0.104 \\
(0.082)\end{array}$ & $\begin{array}{c}0.070 \\
(0.080)\end{array}$ & $\begin{array}{c}0.068 \\
(0.080)\end{array}$ & $\begin{array}{c}0.068 \\
(0.080)\end{array}$ & $\begin{array}{c}0.068 \\
(0.080)\end{array}$ & $\begin{array}{c}0.068 \\
(0.080)\end{array}$ \\
\hline Demographic Controls & no & yes & yes & yes & yes & yes \\
\hline School Employment Controls & no & no & yes & yes & yes & yes \\
\hline Police Employment Controls & no & no & no & yes & yes & yes \\
\hline Social Services Employment Controls & no & no & no & no & yes & yes \\
\hline Hospital Employment Controls & no & no & no & no & no & yes \\
\hline \multicolumn{7}{|l|}{ Panel B: Physical Abuse } \\
\hline Mass-Layoffs-to-Population Ratio & $\begin{array}{c}0.118 \\
(0.100)\end{array}$ & $\begin{array}{c}0.102 \\
(0.079)\end{array}$ & $\begin{array}{c}0.100 \\
(0.080)\end{array}$ & $\begin{array}{c}0.101 \\
(0.080)\end{array}$ & $\begin{array}{c}0.101 \\
(0.080)\end{array}$ & $\begin{array}{c}0.100 \\
(0.080)\end{array}$ \\
\hline Demographic Controls & no & yes & yes & yes & yes & yes \\
\hline School Employment Controls & no & no & yes & yes & yes & yes \\
\hline Police Employment Controls & no & no & no & yes & yes & yes \\
\hline Social Services Employment Controls & no & no & no & no & yes & yes \\
\hline Hospital Employment Controls & no & no & no & no & no & yes \\
\hline \multicolumn{7}{|l|}{ Panel C: Psychological Abuse } \\
\hline Mass-Layoffs-to-Population Ratio & $\begin{array}{c}0.008 \\
(0.107)\end{array}$ & $\begin{array}{c}0.061 \\
(0.083)\end{array}$ & $\begin{array}{c}0.057 \\
(0.081)\end{array}$ & $\begin{array}{c}0.054 \\
(0.080)\end{array}$ & $\begin{array}{c}0.051 \\
(0.079)\end{array}$ & $\begin{array}{c}0.052 \\
(0.079)\end{array}$ \\
\hline Demographic Controls & no & yes & yes & yes & yes & yes \\
\hline School Employment Controls & no & no & yes & yes & yes & yes \\
\hline Police Employment Controls & no & no & no & yes & yes & yes \\
\hline Social Services Employment Controls & no & no & no & no & yes & yes \\
\hline Hospital Employment Controls & no & no & no & no & no & yes \\
\hline \multicolumn{7}{|l|}{ Panel D: Sexual Abuse } \\
\hline Mass-Layoffs-to-Population Ratio & $\begin{array}{l}0.150^{*} \\
(0.088)\end{array}$ & $\begin{array}{c}0.056 \\
(0.066)\end{array}$ & $\begin{array}{c}0.055 \\
(0.066)\end{array}$ & $\begin{array}{c}0.055 \\
(0.066)\end{array}$ & $\begin{array}{c}0.055 \\
(0.067)\end{array}$ & $\begin{array}{c}0.054 \\
(0.067)\end{array}$ \\
\hline Demographic Controls & no & yes & yes & yes & yes & yes \\
\hline School Employment Controls & no & no & yes & yes & yes & yes \\
\hline Police Employment Controls & no & no & no & yes & yes & yes \\
\hline Social Services Employment Controls & no & no & no & no & yes & yes \\
\hline Hospital Employment Controls & no & no & no & no & no & yes \\
\hline
\end{tabular}

Notes: The sample includes 812 county-year observations for 58 California counties from 1996 to 2009. The dependent variables is the log of the number of reports per 100,000 children - these are calculated using California Department of Justice data on reports and population data from the National Cancer Institute's Surveillance Epidemiology and End Results program. Mass-layoffs-to-population ratios are constructed using mass layoff data from the Bureau of Labor Statistics and the working-age population in the previous year. All estimates based on regression models that include year fixed effects, county fixed effects, and county-specific trends. The estimates are weighted by the number of children in each county in each year. Demographic controls include the fraction of residents who are black, the fraction of residents who are Hispanic, and the fraction of residents who are neither black nor Hispanic. Controls for school, police, social services, and hospital employment include the level of employment per capita and an indicator variable to control for cases with a missing value. School employment, social services employment, and hospital employment are based on County Business Patterns Data while police employment data are from the Uniform Crime Reports' Police Employee (LEOKA) Database. Robust standard errors, clustered on counties, are in parentheses.

Significance at $1 \%, 5 \%, 10 \%$ levels are indicated by $* * *, * *$, and $*$, respectively. 
Table 5

Mass-Layoff-to-Population Ratios By Gender and Child Abuse Reports in California

\begin{tabular}{|c|c|c|c|c|c|c|}
\hline & (1) & $(2)$ & (3) & $(4)$ & $(5)$ & (6) \\
\hline \multicolumn{7}{|l|}{ Panel A: All Types of Abuse } \\
\hline Male Mass-Layoffs-to-Population Ratio & $\begin{array}{c}0.256^{* * *} \\
(0.054)\end{array}$ & $\begin{array}{c}0.300^{* * *} \\
(0.054)\end{array}$ & $\begin{array}{c}0.304^{* * *} \\
(0.054)\end{array}$ & $\begin{array}{c}0.307^{* * *} \\
(0.054)\end{array}$ & $\begin{array}{c}0.307^{* * *} \\
(0.054)\end{array}$ & $\begin{array}{c}0.309^{* * *} \\
(0.054)\end{array}$ \\
\hline Female Mass-Layoffs-to-Population Ratio & $\begin{array}{c}-0.217^{* *} \\
(0.085)\end{array}$ & $\begin{array}{c}-0.313^{* * *} \\
(0.071)\end{array}$ & $\begin{array}{c}-0.322^{* * *} \\
(0.072)\end{array}$ & $\begin{array}{c}-0.324^{* * *} \\
(0.072)\end{array}$ & $\begin{array}{c}-0.324^{* * *} \\
(0.072)\end{array}$ & $\begin{array}{c}-0.327^{* * *} \\
(0.073)\end{array}$ \\
\hline Demographic Controls & no & yes & yes & yes & yes & yes \\
\hline School Employment Controls & no & no & yes & yes & yes & yes \\
\hline Police Employment Controls & no & no & no & yes & yes & yes \\
\hline Social Services Employment Controls & no & no & no & no & yes & yes \\
\hline Hospital Employment Controls & no & no & no & no & no & yes \\
\hline \multicolumn{7}{|l|}{ Panel B: Physical Abuse } \\
\hline Male Mass-Layoffs-to-Population Ratio & $\begin{array}{c}0.257^{* * *} \\
(0.067)\end{array}$ & $\begin{array}{c}0.342^{* * *} \\
(0.060)\end{array}$ & $\begin{array}{c}0.346^{* * *} \\
(0.060)\end{array}$ & $\begin{array}{c}0.350^{* * *} \\
(0.059)\end{array}$ & $\begin{array}{c}0.350^{* * *} \\
(0.060)\end{array}$ & $\begin{array}{c}0.352^{* * *} \\
(0.060)\end{array}$ \\
\hline Female Mass-Layoffs-to-Population Ratio & $\begin{array}{c}-0.202^{* *} \\
(0.096)\end{array}$ & $\begin{array}{c}-0.332^{* * *} \\
(0.081)\end{array}$ & $\begin{array}{c}-0.340^{* * *} \\
(0.083)\end{array}$ & $\begin{array}{c}-0.343^{* * *} \\
(0.083)\end{array}$ & $\begin{array}{c}-0.343^{* * *} \\
(0.083)\end{array}$ & $\begin{array}{c}-0.346^{* * *} \\
(0.084)\end{array}$ \\
\hline Demographic Controls & no & yes & yes & yes & yes & yes \\
\hline School Employment Controls & no & no & yes & yes & yes & yes \\
\hline Police Employment Controls & no & no & no & yes & yes & yes \\
\hline Social Services Employment Controls & no & no & no & no & yes & yes \\
\hline Hospital Employment Controls & no & no & no & no & no & yes \\
\hline \multicolumn{7}{|l|}{ Panel C: Psychological Abuse } \\
\hline Male Mass-Layoffs-to-Population Ratio & $\begin{array}{l}0.206^{*} \\
(0.121)\end{array}$ & $\begin{array}{c}0.309^{* * *} \\
(0.088)\end{array}$ & $\begin{array}{c}0.318^{* * *} \\
(0.089)\end{array}$ & $\begin{array}{c}0.312^{* * *} \\
(0.090)\end{array}$ & $\begin{array}{c}0.306^{* * * *} \\
(0.087)\end{array}$ & $\begin{array}{c}0.306^{* * *} \\
(0.087)\end{array}$ \\
\hline Female Mass-Layoffs-to-Population Ratio & $\begin{array}{c}-0.263^{* *} \\
(0.123)\end{array}$ & $\begin{array}{c}-0.335^{* * *} \\
(0.125)\end{array}$ & $\begin{array}{c}-0.352^{* * *} \\
(0.121)\end{array}$ & $\begin{array}{c}-0.347^{* * *} \\
(0.122)\end{array}$ & $\begin{array}{c}-0.343^{* * *} \\
(0.118)\end{array}$ & $\begin{array}{c}-0.342^{* * *} \\
(0.119)\end{array}$ \\
\hline Demographic Controls & no & yes & yes & yes & yes & yes \\
\hline School Employment Controls & no & no & yes & yes & yes & yes \\
\hline Police Employment Controls & no & no & no & yes & yes & yes \\
\hline Social Services Employment Controls & no & no & no & no & yes & yes \\
\hline Hospital Employment Controls & no & no & no & no & no & yes \\
\hline \multicolumn{7}{|l|}{ Panel D: Sexual Abuse } \\
\hline Male Mass-Layoffs-to-Population Ratio & $\begin{array}{l}0.182^{*} \\
(0.102)\end{array}$ & $\begin{array}{c}0.142^{* *} \\
(0.062)\end{array}$ & $\begin{array}{c}0.143^{* *} \\
(0.063)\end{array}$ & $\begin{array}{c}0.145^{* *} \\
(0.062)\end{array}$ & $\begin{array}{c}0.144^{* *} \\
(0.063)\end{array}$ & $\begin{array}{c}0.146^{* *} \\
(0.063)\end{array}$ \\
\hline Female Mass-Layoffs-to-Population Ratio & $\begin{array}{l}-0.065 \\
(0.093)\end{array}$ & $\begin{array}{l}-0.122 \\
(0.077)\end{array}$ & $\begin{array}{l}-0.124 \\
(0.078)\end{array}$ & $\begin{array}{l}-0.126 \\
(0.078)\end{array}$ & $\begin{array}{l}-0.126 \\
(0.078)\end{array}$ & $\begin{array}{l}-0.129 \\
(0.078)\end{array}$ \\
\hline Demographic Controls & no & yes & yes & yes & yes & yes \\
\hline School Employment Controls & no & no & yes & yes & yes & yes \\
\hline Police Employment Controls & no & no & no & yes & yes & yes \\
\hline Social Services Employment Controls & no & no & no & no & yes & yes \\
\hline Hospital Employment Controls & no & no & no & no & no & yes \\
\hline
\end{tabular}

Notes: See Table 4.

Significance at $1 \%, 5 \%, 10 \%$ levels are indicated by $* * *, * *$, and $*$, respectively. 
Table 6

Sample Means from the American Time Use Survey

\begin{tabular}{lcc}
\hline & Fathers' Time Use Sample & Mothers' Time Use Sample \\
\cline { 2 - 3 } Minutes With Children & 251.03 & 385.33 \\
Minutes Alone With Children & 87.12 & 229.44 \\
Minutes Primary Childcare & 54.13 & 109.34 \\
Father Employed in CPS Survey & 0.90 & 0.90 \\
Father Employed in CPS Survey & 0.90 & 0.90 \\
Mother Employed in CPS Survey & 0.65 & 0.60 \\
Mother Employed in CPS Survey & 0.65 & 0.60 \\
Father's Age & 39.60 & 39.67 \\
Mother's Age & 37.52 & 37.30 \\
Father is White & 0.85 & 0.84 \\
Father is Black & 0.08 & 0.06 \\
Father is Other Race & 0.07 & 0.07 \\
Father is Hispanic & 0.19 & 0.19 \\
Mother is White & 0.84 & 0.87 \\
Mother is Black & 0.07 & 0.06 \\
Mother is Other Race & 0.07 & 0.07 \\
Mother is Hispanic & 0.19 & 0.20 \\
Father's Education $<$ HS & 0.13 & 0.13 \\
Father's Education = HS & 0.29 & 0.27 \\
Father Has Some College & 0.24 & 0.28 \\
Father Has 4+ Years College & 0.34 & 0.35 \\
Mother's Education < HS & 0.11 & 0.12 \\
Mother's Education = HS & 0.24 & 0.26 \\
Mother Has Some College & 0.32 & 0.26 \\
Mother Has 4+ Years College & 0.37 & 0.36 \\
Age of Youngest Child & 6.52 & 6.43 \\
Household Size & 4.27 & 4.29 \\
Observations & 12985 & 15456 \\
\hline
\end{tabular}

Notes: Data are from the the American Time Use Survey, 2003-2011. The sample is limited to individuals living with a spouse or partner in a household with a child under the age of 18. Estimates are weighted using ATUS sampling weights. 
Table 7

Parental Employment Status And Parents' Time Spent With Children

Evidence from the American Time Use Survey

\begin{tabular}{|c|c|c|c|c|c|c|}
\hline & \multicolumn{3}{|c|}{ Father's Time With Children } & \multicolumn{3}{|c|}{ Mother's Time With Children } \\
\hline & (1) & $(2)$ & (3) & (4) & (5) & (6) \\
\hline \multicolumn{7}{|c|}{ Panel A: Minutes With Children Around } \\
\hline Father is Not Employed & $\begin{array}{c}62.280^{* * *} \\
(9.896)\end{array}$ & $\begin{array}{c}100.274^{* * *} \\
(9.195)\end{array}$ & $\begin{array}{c}96.636^{* * *} \\
(12.008)\end{array}$ & $\begin{array}{c}-76.144^{* * *} \\
(9.211)\end{array}$ & $\begin{array}{c}-37.545^{* * *} \\
(8.018)\end{array}$ & $\begin{array}{c}-24.824^{* *} \\
(10.055)\end{array}$ \\
\hline Mother is Not Employed & $\begin{array}{l}8.995^{*} \\
(4.822)\end{array}$ & $\begin{array}{l}-1.900 \\
(4.629)\end{array}$ & $\begin{array}{c}0.796 \\
(7.382)\end{array}$ & $\begin{array}{c}173.503^{* * *} \\
(5.148)\end{array}$ & $\begin{array}{c}143.206^{* * *} \\
(4.660)\end{array}$ & $\begin{array}{c}117.476^{* * * *} \\
(7.845)\end{array}$ \\
\hline Observations & 12985 & 12985 & 12980 & 15456 & 15456 & 15451 \\
\hline Demographic Controls & no & yes & yes & no & yes & yes \\
\hline Prior-Economic-Circumstances Controls & no & no & yes & no & no & yes \\
\hline \multicolumn{7}{|l|}{ Panel B: Minutes Alone With Children } \\
\hline Father is Not Employed & $\begin{array}{c}47.824^{* * *} * \\
(6.981)\end{array}$ & $\begin{array}{c}62.056^{* * *} \\
(6.889)\end{array}$ & $\begin{array}{c}52.953^{* * *} \\
(8.815)\end{array}$ & $\begin{array}{c}-85.836^{* * *} \\
(6.920)\end{array}$ & $\begin{array}{c}-59.537 * * * \\
(6.511)\end{array}$ & $\begin{array}{c}-50.452^{* * *} \\
(8.067)\end{array}$ \\
\hline Mother is Not Employed & $\begin{array}{c}-30.966 * * * \\
(3.285)\end{array}$ & $\begin{array}{c}-33.703^{* * *} \\
(3.012)\end{array}$ & $\begin{array}{c}-25.626^{* * *} \\
(4.390)\end{array}$ & $\begin{array}{c}131.865^{* * *} \\
(4.503)\end{array}$ & $\begin{array}{c}115.215^{* * *} \\
\quad(4.133)\end{array}$ & $\begin{array}{c}95.007^{* * *} \\
(6.954)\end{array}$ \\
\hline Observations & 12985 & 12985 & 12980 & 15456 & 15456 & 15451 \\
\hline Demographic Controls & no & yes & yes & no & yes & yes \\
\hline Prior-Economic-Circumstances Controls & no & no & yes & no & no & yes \\
\hline \multicolumn{7}{|c|}{ Panel D: Minutes Doing Primary Childcare } \\
\hline Father is Not Employed & $\begin{array}{c}21.354^{* * *} \\
(4.015)\end{array}$ & $\begin{array}{c}36.167^{* * *} \\
(3.785)\end{array}$ & $\begin{array}{c}25.253^{* * *} \\
\quad(5.331)\end{array}$ & $\begin{array}{c}-30.365^{* * *} \\
(3.824)\end{array}$ & $\begin{array}{c}-9.946^{* * *} \\
(3.395)\end{array}$ & $\begin{array}{l}-7.726^{*} \\
(4.162)\end{array}$ \\
\hline Mother is Not Employed & $\begin{array}{l}-3.248 \\
(2.306)\end{array}$ & $\begin{array}{c}-8.053^{* * *} \\
(1.966)\end{array}$ & $\begin{array}{l}-4.997 \\
(3.715)\end{array}$ & $\begin{array}{c}62.109^{* * *} \\
(2.549)\end{array}$ & $\begin{array}{c}52.386^{* * *} \\
(2.334)\end{array}$ & $\begin{array}{c}38.802^{* * *} \\
(4.103)\end{array}$ \\
\hline Observations & 12985 & 12985 & 12980 & 15456 & 15456 & 15451 \\
\hline Demographic Controls & no & yes & yes & no & yes & yes \\
\hline Prior-Economic-Circumstances Controls & no & no & yes & no & no & yes \\
\hline
\end{tabular}

Notes: Data are from the the American Time Use Survey, 2003-2011. The sample is limited to individuals living with a spouse or partner in a household with a child under the age of 18. All columns control for survey year fixed effects and day of week fixed effects. The estimates in columns 2 and 5 additionally control for age fixed effects, spouse's age fixed effects, educational attainment (less than high school, exactly high school, some college, or four-or-more years of college) fixed effects, spouse's educational attainment fixed effects, race (white, black, or other) and ethnicity (Hispanic or non-Hispanic) fixed effects, spouse's race and ethnicity fixed effects, state fixed effects, age of youngest child fixed effects, and household size fixed effects. Columns 3 and 6 use employment and income information from the CPS, taken two to five months prior to the time use survey. In particular, it incorporates controls for the triple interaction of the individual's employment status, spouse's employment status, and prior year family income at the time of the CPS, in addition to fixed effects for the industry, occupation and hours usually worked for the individual and the spouse (with additional categories created for these variables for those who were not working at the time of the CPS). Estimates are weighted using ATUS sampling weights. Heteroskedastic-robust standard errors are shown in parentheses.

Significance at $1 \%, 5 \%, 10 \%$ levels are indicated by $* * *, * *$, and $*$, respectively. 


\title{
Appendix A.1
}

\section{Additional Figures}

\author{
Figure A1
}

Unemployment Rates and Detrended Child Abuse Reports in California, 1996-2009

Panel A: All Abuse

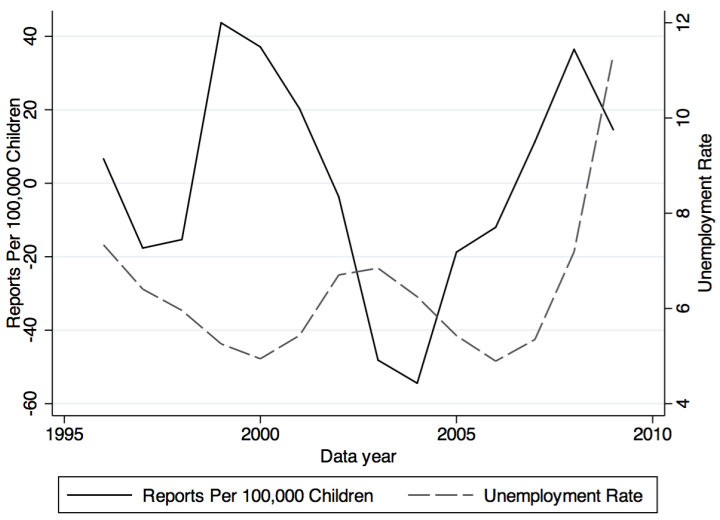

Panel C: Psychological Abuse

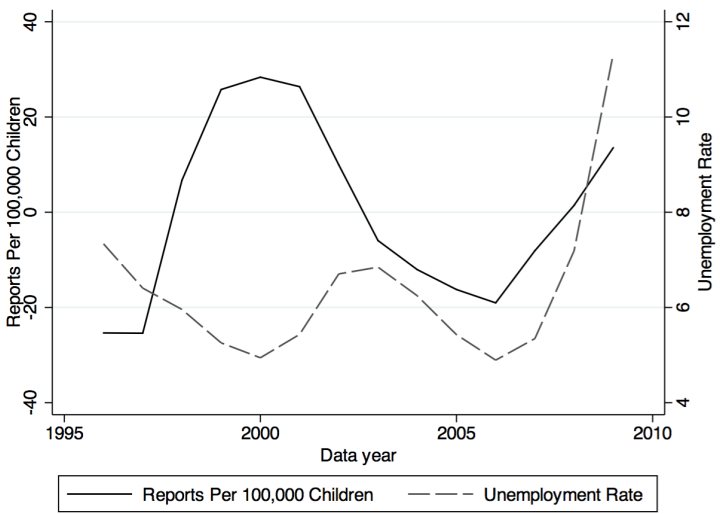

Panel B: Physical Abuse

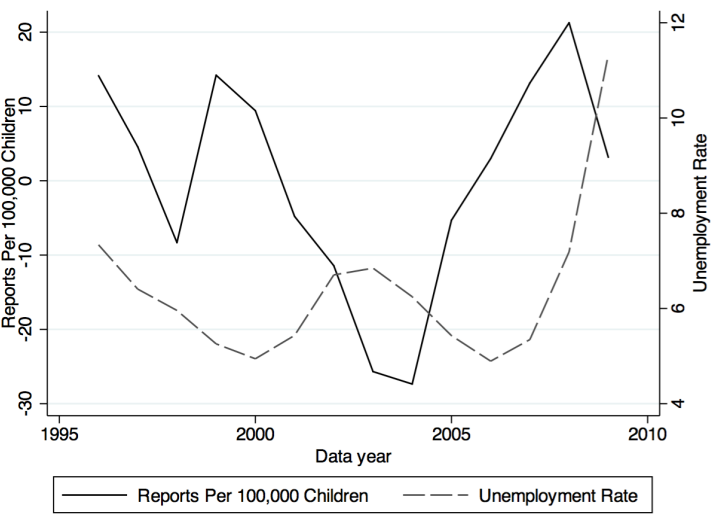

Panel D: Sexual Abuse

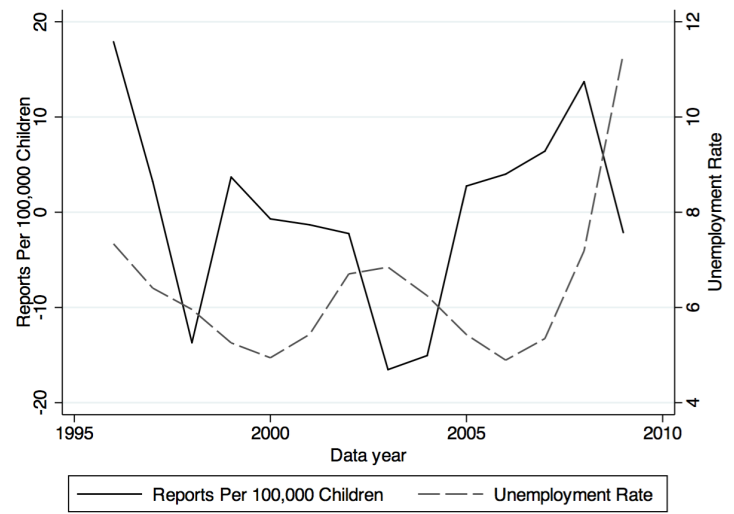

Notes: The number of reports per 100,000 children are calculated using California Department of Justice data on reports and population data from the National Cancer Institute's Surveillance Epidemiology and End Results program. Unemployment rates are based on data from the Bureau of Labor Statistics. 
Figure A2

Male and Female Mass Layoffs-to-Population Ratios in California Counties

Panel A: Unadjusted

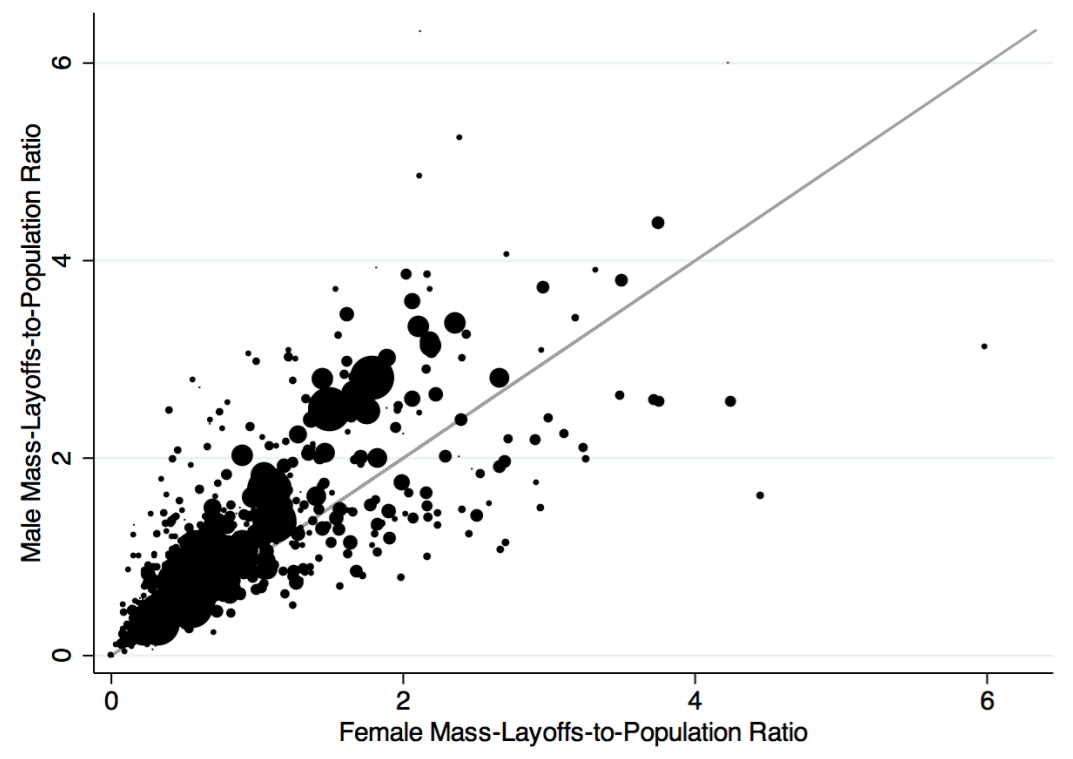

Panel B: Adjusted for county fixed effects, year fixed effects, and year fixed effects

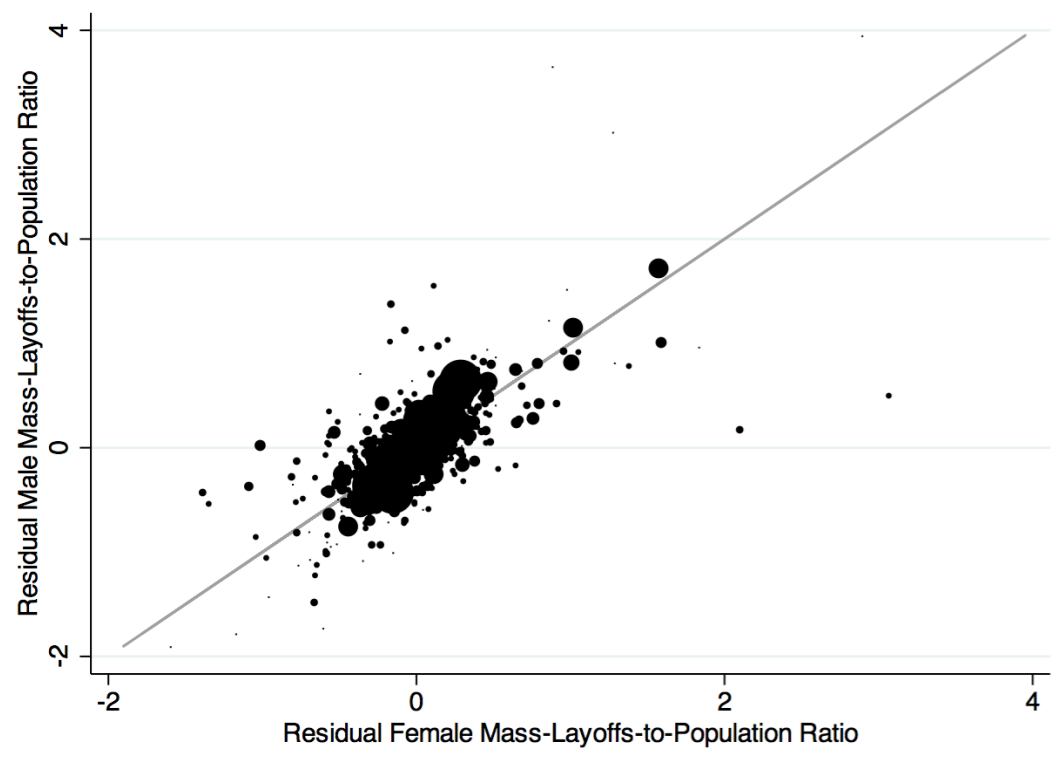

Notes: The sample includes 812 county-year observations for 58 California counties from 1996 to 2009. Mass-layoffs-topopulation ratios are constructed using mass layoff data from the Bureau of Labor Statistics and the working-age population in the previous year. 
Appendix A.2

\section{Additional Estimates of the Effects of Economic}

\section{Conditions on Abuse}

The following not-for-publication tables are analogous to the tables presenting our main results but do not use observations where employment in any high-reporting sector is missing. As such, they are based on 702 observations from 54 counties. 
Table A1

Unemployment Rates and Child Abuse Reports in California

\begin{tabular}{|c|c|c|c|c|c|c|}
\hline & (1) & $(2)$ & $(3)$ & $(4)$ & $(5)$ & $(6)$ \\
\hline \multicolumn{7}{|l|}{ Panel A: All Types of Abuse } \\
\hline Unemployment Rate & $\begin{array}{c}0.010 \\
(0.037)\end{array}$ & $\begin{array}{c}0.004 \\
(0.041)\end{array}$ & $\begin{array}{c}0.004 \\
(0.041)\end{array}$ & $\begin{array}{c}0.004 \\
(0.041)\end{array}$ & $\begin{array}{c}0.004 \\
(0.041)\end{array}$ & $\begin{array}{c}0.003 \\
(0.041)\end{array}$ \\
\hline Demographic Controls & no & yes & yes & yes & yes & yes \\
\hline School Employment Controls & no & no & yes & yes & yes & yes \\
\hline Police Employment Controls & no & no & no & yes & yes & yes \\
\hline Social Services Employment Controls & no & no & no & no & yes & yes \\
\hline Hospital Employment Controls & no & no & no & no & no & yes \\
\hline \multicolumn{7}{|l|}{ Panel B: Physical Abuse } \\
\hline Unemployment Rate & $\begin{array}{l}-0.008 \\
(0.040)\end{array}$ & $\begin{array}{c}0.003 \\
(0.044)\end{array}$ & $\begin{array}{c}0.003 \\
(0.044)\end{array}$ & $\begin{array}{c}0.003 \\
(0.044)\end{array}$ & $\begin{array}{c}0.003 \\
(0.044)\end{array}$ & $\begin{array}{c}0.003 \\
(0.043)\end{array}$ \\
\hline Demographic Controls & no & yes & yes & yes & yes & yes \\
\hline School Employment Controls & no & no & yes & yes & yes & yes \\
\hline Police Employment Controls & no & no & no & yes & yes & yes \\
\hline Social Services Employment Controls & no & no & no & no & yes & yes \\
\hline Hospital Employment Controls & no & no & no & no & no & yes \\
\hline \multicolumn{7}{|l|}{ Panel C: Psychological Abuse } \\
\hline Unemployment Rate & $\begin{array}{c}-0.062 \\
(0.052)\end{array}$ & $\begin{array}{c}-0.033 \\
(0.058)\end{array}$ & $\begin{array}{c}-0.033 \\
(0.057)\end{array}$ & $\begin{array}{c}-0.032 \\
(0.057)\end{array}$ & $\begin{array}{c}-0.034 \\
(0.055)\end{array}$ & $\begin{array}{c}-0.034 \\
(0.055)\end{array}$ \\
\hline Demographic Controls & no & yes & yes & yes & yes & yes \\
\hline School Employment Controls & no & no & yes & yes & yes & yes \\
\hline Police Employment Controls & no & no & no & yes & yes & yes \\
\hline Social Services Employment Controls & no & no & no & no & yes & yes \\
\hline Hospital Employment Controls & no & no & no & no & no & yes \\
\hline \multicolumn{7}{|l|}{ Panel D: Sexual Abuse } \\
\hline Unemployment Rate & $\begin{array}{c}0.057 \\
(0.068)\end{array}$ & $\begin{array}{c}0.009 \\
(0.040)\end{array}$ & $\begin{array}{c}0.009 \\
(0.040)\end{array}$ & $\begin{array}{c}0.008 \\
(0.040)\end{array}$ & $\begin{array}{c}0.008 \\
(0.040)\end{array}$ & $\begin{array}{c}0.008 \\
(0.040)\end{array}$ \\
\hline Demographic Controls & no & yes & yes & yes & yes & yes \\
\hline School Employment Controls & no & no & yes & yes & yes & yes \\
\hline Police Employment Controls & no & no & no & yes & yes & yes \\
\hline Social Services Employment Controls & no & no & no & no & yes & yes \\
\hline Hospital Employment Controls & no & no & no & no & no & yes \\
\hline
\end{tabular}

Notes: See Table 2.

Significance at $1 \%, 5 \%, 10 \%$ levels are indicated by ${ }^{* * *}, * *$, and $*$, respectively. 
Table A2

Employment-to-Population Ratios and Child Abuse Reports in California

\begin{tabular}{|c|c|c|c|c|c|c|}
\hline & (1) & $(2)$ & $(3)$ & $(4)$ & $(5)$ & $(6)$ \\
\hline \multicolumn{7}{|l|}{ Panel A: All Types of Abuse } \\
\hline Employment-to-Population Ratio & $\begin{array}{c}0.015 \\
(0.038)\end{array}$ & $\begin{array}{c}-0.008 \\
(0.030)\end{array}$ & $\begin{array}{c}-0.010 \\
(0.030)\end{array}$ & $\begin{array}{c}-0.010 \\
(0.030)\end{array}$ & $\begin{array}{c}-0.010 \\
(0.030)\end{array}$ & $\begin{array}{c}-0.009 \\
(0.030)\end{array}$ \\
\hline Demographic Controls & no & yes & yes & yes & yes & yes \\
\hline School Employment Controls & no & no & yes & yes & yes & yes \\
\hline Police Employment Controls & no & no & no & yes & yes & yes \\
\hline Social Services Employment Controls & no & no & no & no & yes & yes \\
\hline Hospital Employment Controls & no & no & no & no & no & yes \\
\hline \multicolumn{7}{|l|}{ Panel B: Physical Abuse } \\
\hline Employment-to-Population Ratio & $\begin{array}{c}0.028 \\
(0.038)\end{array}$ & $\begin{array}{c}-0.005 \\
(0.031)\end{array}$ & $\begin{array}{c}-0.007 \\
(0.031)\end{array}$ & $\begin{array}{c}-0.008 \\
(0.031)\end{array}$ & $\begin{array}{c}-0.007 \\
(0.032)\end{array}$ & $\begin{array}{c}-0.006 \\
(0.032)\end{array}$ \\
\hline Demographic Controls & no & yes & yes & yes & yes & yes \\
\hline School Employment Controls & no & no & yes & yes & yes & yes \\
\hline Police Employment Controls & no & no & no & yes & yes & yes \\
\hline Social Services Employment Controls & no & no & no & no & yes & yes \\
\hline Hospital Employment Controls & no & no & no & no & no & yes \\
\hline \multicolumn{7}{|l|}{ Panel C: Psychological Abuse } \\
\hline Employment-to-Population Ratio & $\begin{array}{c}0.019 \\
(0.043)\end{array}$ & $\begin{array}{c}-0.001 \\
(0.045)\end{array}$ & $\begin{array}{c}-0.005 \\
(0.043)\end{array}$ & $\begin{array}{c}-0.003 \\
(0.044)\end{array}$ & $\begin{array}{c}-0.004 \\
(0.043)\end{array}$ & $\begin{array}{c}-0.005 \\
(0.043)\end{array}$ \\
\hline Demographic Controls & no & yes & yes & yes & yes & yes \\
\hline School Employment Controls & no & no & yes & yes & yes & yes \\
\hline Police Employment Controls & no & no & no & yes & yes & yes \\
\hline Social Services Employment Controls & no & no & no & no & yes & yes \\
\hline Hospital Employment Controls & no & no & no & no & no & yes \\
\hline \multicolumn{7}{|l|}{ Panel D: Sexual Abuse } \\
\hline Employment-to-Population Ratio & $\begin{array}{c}-0.011 \\
(0.035)\end{array}$ & $\begin{array}{c}-0.026 \\
(0.026)\end{array}$ & $\begin{array}{l}-0.026 \\
(0.027)\end{array}$ & $\begin{array}{l}-0.027 \\
(0.027)\end{array}$ & $\begin{array}{l}-0.027 \\
(0.027)\end{array}$ & $\begin{array}{c}-0.026 \\
(0.027)\end{array}$ \\
\hline Demographic Controls & no & yes & yes & yes & yes & yes \\
\hline School Employment Controls & no & no & yes & yes & yes & yes \\
\hline Police Employment Controls & no & no & no & yes & yes & yes \\
\hline Social Services Employment Controls & no & no & no & no & yes & yes \\
\hline Hospital Employment Controls & no & no & no & no & no & yes \\
\hline
\end{tabular}

Notes: See Table 3.

Significance at $1 \%, 5 \%, 10 \%$ levels are indicated by ${ }^{* * *}, * *$, and $*$, respectively. 
Table A3

Mass-Layoff-to-Population Ratios and Child Abuse Reports in California

\begin{tabular}{|c|c|c|c|c|c|c|}
\hline & (1) & $(2)$ & (3) & $(4)$ & $(5)$ & (6) \\
\hline \multicolumn{7}{|l|}{ Panel A: All Types of Abuse } \\
\hline Mass-Layoffs-to-Population Ratio & $\begin{array}{c}0.103 \\
(0.084)\end{array}$ & $\begin{array}{c}0.067 \\
(0.082)\end{array}$ & $\begin{array}{c}0.066 \\
(0.082)\end{array}$ & $\begin{array}{c}0.067 \\
(0.082)\end{array}$ & $\begin{array}{c}0.067 \\
(0.083)\end{array}$ & $\begin{array}{c}0.066 \\
(0.082)\end{array}$ \\
\hline Demographic Controls & no & yes & yes & yes & yes & yes \\
\hline School Employment Controls & no & no & yes & yes & yes & yes \\
\hline Police Employment Controls & no & no & no & yes & yes & yes \\
\hline Social Services Employment Controls & no & no & no & no & yes & yes \\
\hline Hospital Employment Controls & no & no & no & no & no & yes \\
\hline \multicolumn{7}{|l|}{ Panel B: Physical Abuse } \\
\hline Mass-Layoffs-to-Population Ratio & $\begin{array}{c}0.117 \\
(0.103)\end{array}$ & $\begin{array}{c}0.099 \\
(0.082)\end{array}$ & $\begin{array}{c}0.098 \\
(0.082)\end{array}$ & $\begin{array}{c}0.099 \\
(0.082)\end{array}$ & $\begin{array}{c}0.099 \\
(0.082)\end{array}$ & $\begin{array}{c}0.099 \\
(0.082)\end{array}$ \\
\hline Demographic Controls & no & yes & yes & yes & yes & yes \\
\hline School Employment Controls & no & no & yes & yes & yes & yes \\
\hline Police Employment Controls & no & no & no & yes & yes & yes \\
\hline Social Services Employment Controls & no & no & no & no & yes & yes \\
\hline Hospital Employment Controls & no & no & no & no & no & yes \\
\hline \multicolumn{7}{|l|}{ Panel C: Psychological Abuse } \\
\hline Mass-Layoffs-to-Population Ratio & $\begin{array}{c}0.002 \\
(0.111)\end{array}$ & $\begin{array}{c}0.056 \\
(0.086)\end{array}$ & $\begin{array}{c}0.053 \\
(0.084)\end{array}$ & $\begin{array}{c}0.050 \\
(0.083)\end{array}$ & $\begin{array}{c}0.046 \\
(0.082)\end{array}$ & $\begin{array}{c}0.046 \\
(0.082)\end{array}$ \\
\hline Demographic Controls & no & yes & yes & yes & yes & yes \\
\hline School Employment Controls & no & no & yes & yes & yes & yes \\
\hline Police Employment Controls & no & no & no & yes & yes & yes \\
\hline Social Services Employment Controls & no & no & no & no & yes & yes \\
\hline Hospital Employment Controls & no & no & no & no & no & yes \\
\hline \multicolumn{7}{|l|}{ Panel D: Sexual Abuse } \\
\hline Mass-Layoffs-to-Population Ratio & $\begin{array}{l}0.153^{*} \\
(0.090)\end{array}$ & $\begin{array}{c}0.053 \\
(0.069)\end{array}$ & $\begin{array}{c}0.053 \\
(0.068)\end{array}$ & $\begin{array}{c}0.054 \\
(0.068)\end{array}$ & $\begin{array}{c}0.054 \\
(0.069)\end{array}$ & $\begin{array}{c}0.053 \\
(0.069)\end{array}$ \\
\hline Demographic Controls & no & yes & yes & yes & yes & yes \\
\hline School Employment Controls & no & no & yes & yes & yes & yes \\
\hline Police Employment Controls & no & no & no & yes & yes & yes \\
\hline Social Services Employment Controls & no & no & no & no & yes & yes \\
\hline Hospital Employment Controls & no & no & no & no & no & yes \\
\hline
\end{tabular}

Notes: See Table 4.

Significance at $1 \%, 5 \%, 10 \%$ levels are indicated by ${ }^{* * *},{ }^{* *}$, and $*$, respectively. 
Table A4

Mass-Layoff-to-Population Ratios By Gender and Child Abuse Reports in California

\begin{tabular}{|c|c|c|c|c|c|c|}
\hline & (1) & $(2)$ & (3) & $(4)$ & $(5)$ & (6) \\
\hline \multicolumn{7}{|l|}{ Panel A: All Types of Abuse } \\
\hline Male Mass-Layoffs-to-Population Ratio & $\begin{array}{c}0.259^{* * *} \\
(0.056)\end{array}$ & $\begin{array}{c}0.303^{* * *} \\
(0.057)\end{array}$ & $\begin{array}{c}0.306^{* * *} \\
(0.057)\end{array}$ & $\begin{array}{c}0.309^{* * *} \\
(0.056)\end{array}$ & $\begin{array}{c}0.310^{* * *} \\
(0.056)\end{array}$ & $\begin{array}{c}0.312^{* * *} \\
(0.056)\end{array}$ \\
\hline Female Mass-Layoffs-to-Population Ratio & $\begin{array}{c}-0.222^{* *} \\
(0.089)\end{array}$ & $\begin{array}{c}-0.323^{* * *} \\
(0.074)\end{array}$ & $\begin{array}{c}-0.329^{* * *} \\
(0.077)\end{array}$ & $\begin{array}{c}-0.332^{* * *} \\
(0.077)\end{array}$ & $\begin{array}{c}-0.332^{* * *} \\
(0.076)\end{array}$ & $\begin{array}{c}-0.336^{* * *} \\
(0.077)\end{array}$ \\
\hline Demographic Controls & no & yes & yes & yes & yes & yes \\
\hline School Employment Controls & no & no & yes & yes & yes & yes \\
\hline Police Employment Controls & no & no & no & yes & yes & yes \\
\hline Social Services Employment Controls & no & no & no & no & yes & yes \\
\hline Hospital Employment Controls & no & no & no & no & no & yes \\
\hline \multicolumn{7}{|l|}{ Panel B: Physical Abuse } \\
\hline Male Mass-Layoffs-to-Population Ratio & $\begin{array}{c}0.259^{* * *} \\
(0.070)\end{array}$ & $\begin{array}{c}0.346^{* * *} \\
(0.063)\end{array}$ & $\begin{array}{c}0.349^{* * *} \\
(0.063)\end{array}$ & $\begin{array}{c}0.353^{* * *} \\
(0.062)\end{array}$ & $\begin{array}{c}0.355^{* * *} \\
(0.062)\end{array}$ & $\begin{array}{c}0.356^{* * *} \\
(0.063)\end{array}$ \\
\hline Female Mass-Layoffs-to-Population Ratio & $\begin{array}{c}-0.208^{* *} \\
(0.101)\end{array}$ & $\begin{array}{c}-0.344^{* * *} \\
(0.085)\end{array}$ & $\begin{array}{c}-0.350^{* * *} \\
(0.088)\end{array}$ & $\begin{array}{c}-0.353^{* * *} \\
(0.088)\end{array}$ & $\begin{array}{c}-0.354^{* * *} \\
(0.088)\end{array}$ & $\begin{array}{c}-0.357^{* * *} \\
(0.089)\end{array}$ \\
\hline Demographic Controls & no & yes & yes & yes & yes & yes \\
\hline School Employment Controls & no & no & yes & yes & yes & yes \\
\hline Police Employment Controls & no & no & no & yes & yes & yes \\
\hline Social Services Employment Controls & no & no & no & no & yes & yes \\
\hline Hospital Employment Controls & no & no & no & no & no & yes \\
\hline \multicolumn{7}{|l|}{ Panel C: Psychological Abuse } \\
\hline Male Mass-Layoffs-to-Population Ratio & $\begin{array}{l}0.212^{*} \\
(0.125)\end{array}$ & $\begin{array}{c}0.320^{* * *} \\
(0.092)\end{array}$ & $\begin{array}{c}0.327^{* * *} \\
(0.092)\end{array}$ & $\begin{array}{c}0.320^{* * *} \\
(0.093)\end{array}$ & $\begin{array}{c}0.313^{* * *} \\
(0.089)\end{array}$ & $\begin{array}{c}0.313^{* * *} \\
(0.090)\end{array}$ \\
\hline Female Mass-Layoffs-to-Population Ratio & $\begin{array}{c}-0.279^{* *} \\
(0.129)\end{array}$ & $\begin{array}{c}-0.359^{* * *} \\
(0.132)\end{array}$ & $\begin{array}{c}-0.372^{* * *} \\
(0.129)\end{array}$ & $\begin{array}{c}-0.367^{* * *} \\
(0.129)\end{array}$ & $\begin{array}{c}-0.362^{* * *} \\
(0.124)\end{array}$ & $\begin{array}{c}-0.362^{* * *} \\
(0.125)\end{array}$ \\
\hline Demographic Controls & no & yes & yes & yes & yes & yes \\
\hline School Employment Controls & no & no & yes & yes & yes & yes \\
\hline Police Employment Controls & no & no & no & yes & yes & yes \\
\hline Social Services Employment Controls & no & no & no & no & yes & yes \\
\hline Hospital Employment Controls & no & no & no & no & no & yes \\
\hline \multicolumn{7}{|l|}{ Panel D: Sexual Abuse } \\
\hline Male Mass-Layoffs-to-Population Ratio & $\begin{array}{c}0.176 \\
(0.106)\end{array}$ & $\begin{array}{c}0.134^{* *} \\
(0.065)\end{array}$ & $\begin{array}{c}0.134^{* *} \\
(0.066)\end{array}$ & $\begin{array}{c}0.136^{* *} \\
(0.065)\end{array}$ & $\begin{array}{c}0.136^{* *} \\
(0.066)\end{array}$ & $\begin{array}{c}0.138^{* *} \\
(0.066)\end{array}$ \\
\hline Female Mass-Layoffs-to-Population Ratio & $\begin{array}{l}-0.056 \\
(0.099)\end{array}$ & $\begin{array}{l}-0.116 \\
(0.082)\end{array}$ & $\begin{array}{l}-0.116 \\
(0.083)\end{array}$ & $\begin{array}{l}-0.118 \\
(0.083)\end{array}$ & $\begin{array}{l}-0.118 \\
(0.083)\end{array}$ & $\begin{array}{l}-0.121 \\
(0.083)\end{array}$ \\
\hline Demographic Controls & no & yes & yes & yes & yes & yes \\
\hline School Employment Controls & no & no & yes & yes & yes & yes \\
\hline Police Employment Controls & no & no & no & yes & yes & yes \\
\hline Social Services Employment Controls & no & no & no & no & yes & yes \\
\hline Hospital Employment Controls & no & no & no & no & no & yes \\
\hline
\end{tabular}

Notes: See Table 5.

Significance at $1 \%, 5 \%, 10 \%$ levels are indicated by $* * *, * *$, and $*$, respectively. 


\section{Appendix A.3}

\section{Additional Estimates of the Effects of Parental Employment Status on Time Spent with Childre}

The following not-for-publication tables are analogous to Table 7, which presents evidence from the American Time Use Survey on the relationship between parental employment status and time spent with children, but are estimated on smaller samples. Table A5 presents the results of estimates based on a sample that omits families in which a spouse changes from being unemployed to being employed between the CPS and ATUS surveys. Table A6 presents the results of estimates based on a sample of non-traditional families, including families in which the respondent lives with an unmarried partner and households including step- or foster-children. 
Table A5

Parental Employment Status And Parents' Time Spent With Children

Evidence from the American Time Use Survey

Only Considering Employment to Non-employment Transitions

\begin{tabular}{|c|c|c|c|c|c|c|}
\hline & \multicolumn{3}{|c|}{ Father's Time With Children } & \multicolumn{3}{|c|}{ Mother's Time With Children } \\
\hline & (1) & $(2)$ & (3) & (4) & $(5)$ & (6) \\
\hline \multicolumn{7}{|l|}{ Panel A: Minutes With Children } \\
\hline Father is Not Employed & $\begin{array}{c}61.176^{* * *} \\
(10.140)\end{array}$ & $\begin{array}{c}101.798^{* * *} \\
\quad(9.413)\end{array}$ & $\begin{array}{c}111.834^{* * *} \\
(17.127)\end{array}$ & $\begin{array}{c}-77.782^{* * *} \\
(9.430)\end{array}$ & $\begin{array}{c}-38.692 * * * \\
(8.134)\end{array}$ & $\begin{array}{c}-14.872 \\
(13.610)\end{array}$ \\
\hline Mother is Not Employed & $\begin{array}{c}10.793 * * \\
(4.931)\end{array}$ & $\begin{array}{l}-0.445 \\
(4.768)\end{array}$ & $\begin{array}{c}4.459 \\
(10.243)\end{array}$ & $\begin{array}{c}178.001 * * * \\
\quad(5.297)\end{array}$ & $\begin{array}{c}145.871 * * * \\
\quad(4.772)\end{array}$ & $\begin{array}{c}129.643^{* * *} \\
(11.607)\end{array}$ \\
\hline Observations & 12060 & 12060 & 12058 & 13853 & 13853 & 13850 \\
\hline Demographic Controls & no & yes & yes & no & yes & yes \\
\hline Prior-Economic-Circumstances Controls & no & no & yes & no & no & yes \\
\hline \multicolumn{7}{|l|}{ Panel B: Minutes Alone With Children } \\
\hline Father is Not Employed & $\begin{array}{c}47.879^{* * *} \\
(7.134)\end{array}$ & $\begin{array}{c}63.441^{* * *} \\
(7.002)\end{array}$ & $\begin{array}{c}55.229^{* * *} \\
(12.535)\end{array}$ & $\begin{array}{c}-85.717^{* * *} \\
(7.177)\end{array}$ & $\begin{array}{c}-58.619^{* * *} \\
(6.745)\end{array}$ & $\begin{array}{c}-43.191 * * * \\
(10.984)\end{array}$ \\
\hline Mother is Not Employed & $\begin{array}{c}-31.065^{* * *} \\
(3.359)\end{array}$ & $\begin{array}{c}-33.351 * * * \\
(3.139)\end{array}$ & $\begin{array}{c}-26.628^{* * *} \\
(5.647)\end{array}$ & $\begin{array}{c}134.794^{* * *} \\
\quad(4.646)\end{array}$ & $\begin{array}{c}115.862^{* * *} \\
\quad(4.238)\end{array}$ & $\begin{array}{c}106.181^{* * *} \\
(11.073)\end{array}$ \\
\hline Observations & 12060 & 12060 & 12058 & 13853 & 13853 & 13850 \\
\hline Demographic Controls & no & yes & yes & no & yes & yes \\
\hline Prior-Economic-Circumstances Controls & no & no & yes & no & no & yes \\
\hline \multicolumn{7}{|c|}{ Panel D: Minutes Doing Primary Childcare } \\
\hline Father is Not Employed & $\begin{array}{c}22.910^{* * *} \\
(4.128)\end{array}$ & $\begin{array}{c}38.795^{* * *} \\
(3.838)\end{array}$ & $\begin{array}{c}27.890^{* * *} \\
(6.932)\end{array}$ & $\begin{array}{c}-29.378^{* * *} \\
(3.940)\end{array}$ & $\begin{array}{c}-8.469^{* *} \\
(3.468)\end{array}$ & $\begin{array}{l}-2.816 \\
(5.386)\end{array}$ \\
\hline Mother is Not Employed & $\begin{array}{l}-3.356 \\
(2.299)\end{array}$ & $\begin{array}{c}-8.333^{* * *} \\
(2.001)\end{array}$ & $\begin{array}{l}-6.754 \\
(5.408)\end{array}$ & $\begin{array}{c}64.401 * * * \\
(2.618)\end{array}$ & $\begin{array}{c}54.268^{* * *} \\
(2.374)\end{array}$ & $\begin{array}{c}38.578^{* * *} \\
(6.295)\end{array}$ \\
\hline Observations & 12060 & 12060 & 12058 & 13853 & 13853 & 13850 \\
\hline Demographic Controls & no & yes & yes & no & yes & yes \\
\hline Prior-Economic-Circumstances Controls & no & no & yes & no & no & yes \\
\hline
\end{tabular}

Notes: The sample omits families in which a spouse changes from being unemployed to being employed between the CPS and ATUS surveys. For additional notes, see Table 7.

Significance at $1 \%, 5 \%, 10 \%$ levels are indicated by ${ }^{* * *},{ }^{* *}$, and ${ }^{*}$, respectively. 
Table A6

Parental Employment Status And Parents' Time Spent With Children

Evidence from the American Time Use Survey

Only Considering Non-traditional Couples

\begin{tabular}{|c|c|c|c|c|c|c|}
\hline & \multicolumn{3}{|c|}{ Father's Time With Children } & \multicolumn{3}{|c|}{ Mother's Time With Children } \\
\hline & $(1)$ & $(2)$ & (3) & $(4)$ & (5) & $(6)$ \\
\hline \multicolumn{7}{|l|}{ Panel A: Minutes With Children } \\
\hline Father is Not Employed & $\begin{array}{c}87.065^{* * *} \\
(31.367)\end{array}$ & $\begin{array}{c}110.994^{* * *} \\
(29.446)\end{array}$ & $\begin{array}{c}195.279^{* * *} \\
(50.098)\end{array}$ & $\begin{array}{c}-58.656^{* *} \\
(24.009)\end{array}$ & $\begin{array}{c}-59.054^{* * *} \\
(22.631)\end{array}$ & $\begin{array}{l}-53.455 \\
(45.993)\end{array}$ \\
\hline Mother is Not Employed & $\begin{array}{l}40.648^{*} \\
(24.072)\end{array}$ & $\begin{array}{c}12.338 \\
(20.577)\end{array}$ & $\begin{array}{c}16.123 \\
(43.455)\end{array}$ & $\begin{array}{c}190.278^{* * *} \\
(20.126)\end{array}$ & $\begin{array}{c}137.395^{* * *} \\
(20.064)\end{array}$ & $\begin{array}{c}106.308^{* *} \\
(46.180)\end{array}$ \\
\hline Observations & 872 & 872 & 872 & 955 & 955 & 955 \\
\hline Demographic Controls & no & yes & yes & no & yes & yes \\
\hline Prior-Economic-Circumstances Controls & no & no & yes & no & no & yes \\
\hline \multicolumn{7}{|l|}{ Panel B: Minutes Alone With Children } \\
\hline Father is Not Employed & $\begin{array}{l}58.144^{* *} \\
(22.957)\end{array}$ & $\begin{array}{c}81.444^{* * *} \\
(21.619)\end{array}$ & $\begin{array}{c}101.749^{* *} \\
(42.218)\end{array}$ & $\begin{array}{c}-53.853^{* *} \\
(21.232)\end{array}$ & $\begin{array}{c}-59.920 * * * \\
(19.765)\end{array}$ & $\begin{array}{l}-60.853 \\
(39.700)\end{array}$ \\
\hline Mother is Not Employed & $\begin{array}{l}-23.075 \\
(21.052)\end{array}$ & $\begin{array}{c}-49.094 * * * \\
(14.627)\end{array}$ & $\begin{array}{l}-24.428 \\
(33.917)\end{array}$ & $\begin{array}{c}142.758^{* * *} \\
(18.163)\end{array}$ & $\begin{array}{c}98.079^{* * *} \\
(16.250)\end{array}$ & $\begin{array}{l}68.132 * \\
(35.178)\end{array}$ \\
\hline Observations & 872 & 872 & 872 & 955 & 955 & 955 \\
\hline Demographic Controls & no & yes & yes & no & yes & yes \\
\hline Prior-Economic-Circumstances Controls & no & no & yes & no & no & yes \\
\hline \multicolumn{7}{|c|}{ Panel D: Minutes Doing Primary Childcare } \\
\hline Father is Not Employed & $\begin{array}{c}20.335 \\
(13.041)\end{array}$ & $\begin{array}{c}49.293^{* * *} \\
(13.057)\end{array}$ & $\begin{array}{c}69.571^{* * *} \\
(24.012)\end{array}$ & $\begin{array}{l}-11.687 \\
(11.775)\end{array}$ & $\begin{array}{c}-3.868 \\
(10.547)\end{array}$ & $\begin{array}{c}-8.127 \\
(19.198)\end{array}$ \\
\hline Mother is Not Employed & $\begin{array}{c}11.123 \\
(13.360)\end{array}$ & $\begin{array}{l}-6.948 \\
(9.461)\end{array}$ & $\begin{array}{c}-44.820 * * * \\
(16.319)\end{array}$ & $\begin{array}{c}74.040^{* * * *} \\
(9.168)\end{array}$ & $\begin{array}{c}47.143^{* * *} \\
(9.898)\end{array}$ & $\begin{array}{c}50.641^{* *} \\
(22.120)\end{array}$ \\
\hline Observations & 872 & 872 & 872 & 955 & 955 & 955 \\
\hline Demographic Controls & no & yes & yes & no & yes & yes \\
\hline Prior-Economic-Circumstances Controls & no & no & yes & no & no & yes \\
\hline
\end{tabular}

Notes: The sample is limited to families in which the respondent lives with an unmarried partner and household containing stepchildren or foster children. The sample is restricted to 2007-2011 when this information is available. For additional notes, see Table 7 .

Significance at $1 \%, 5 \%, 10 \%$ levels are indicated by $* * *, * *$, and $*$, respectively. 